Check for updates

Cite this: RSC Adv., 2018, 8, 6954

Received 4th January 2018

Accepted 6th February 2018

DOI: $10.1039 / c 8 r a 00071 a$

rsc.li/rsc-advances

\section{Synthesis, characterization and olefin polymerization behaviors of phenylene-bridged bis- $\beta$-carbonylenamine binuclear titanium complexes $\dagger$}

\author{
Derong Luo, $\stackrel{+}{a}^{a}$ Yi Zeng, $\star^{a}$ Xiong Chen, ${ }^{a}$ Ping Xia, ${ }^{a}$ Guangyong Xie, (D) *a \\ Qingliang You, ${ }^{b} \mathrm{Li}$ Zhang, ${ }^{a}$ Tingcheng $\mathrm{Li}^{\mathrm{a}}$ Xiangdan $\mathrm{Li}^{\mathrm{a}}$ and Aiqing Zhang ${ }^{\mathrm{a}}$
}

Binuclear and multinuclear complexes have attracted much attention due to their unique catalytic performances for olefin polymerization compared with their mononuclear counterparts. In this work, a series of phenyl-bridged bis- $\beta$-carbonylenamine $\left[\mathrm{O}^{-} N S^{R}\right](R=$ alkyl or phenyl) tridentate ligands and their binuclear titanium complexes $\left(\mathrm{Ti}^{2} \mathrm{~L}_{1}-\mathrm{Ti}^{2} \mathrm{~L}_{5}\right)$ were synthesized and characterized by ${ }^{1} \mathrm{H} N M R,{ }^{13} \mathrm{C}$ NMR, FTIR and elemental analysis. The molecular structure of ligand $\mathrm{L}_{2}\left(\mathrm{R}={ }^{n} \mathrm{Pr}\right)$ and its corresponding $\mathrm{Ti}$ complex $\mathrm{Ti}^{2} \mathrm{~L}_{2}$ were further investigated by single-crystal $\mathrm{X}$-ray diffraction, which showed that each titanium coordinated with six atoms to form a distorted octahedral configuration along with the conversion of the ligand from $\beta$-carbonylenamine to $\beta$-imino enol form. Under the activation of MMAO, these complexes catalyzed ethylene polymerization and ethylene/ $\boldsymbol{\alpha}$-olefin copolymerization with extremely high activity (over $10^{6} \mathrm{~g} \mathrm{~mol}\left(\mathrm{Ti}^{-1} \mathrm{~h}^{-1} \mathrm{~atm}^{-1}\right.$ ) to produce high molecular weight polyethylene. At the same time, wider polydispersity as compared with the mononuclear counterpart $\mathrm{TiL}_{6}$ was observed, indicating that two active catalytic centers may be present, consistent with the asymmetrical crystal structure of the binuclear titanium complex. Furthermore, these complexes possessed better thermal stability than their mononuclear analogues. Compared with the complexes bearing alkylthio sidearms, the complex $\mathrm{Ti}^{2} \mathrm{~L}_{5}$ bearing a phenylthio sidearm exhibited higher catalytic activity towards ethylene polymerization and produced polyethylene with much higher molecular weight, but with an appreciably lower 1-hexene incorporation ratio. Nevertheless, these bis- $\beta$-carbonylenamine-derived binuclear titanium complexes showed much higher ethylene/1-hexene copolymerization activity and 1hexene incorporation ratios as compared with the methylene-bridged bis-salicylaldiminato binuclear titanium complexes, and the molecular weight and 1-hexene incorporation ratio could be flexibly tuned by the initial feed of $\alpha$-olefin commoners and catalyst structures.

\section{Introduction}

Polyolefins are by far the most important and most produced synthetic polymers today, and the design and synthesis of effective catalysts for olefin polymerization and copolymerization is of great interest in both academic research and

\footnotetext{
${ }^{a}$ Key Laboratory of Catalysis and Materials Science of the State Ethnic Affairs Commission, Ministry of Education Hubei Province, South-Central University for Nationalities, Wuhan 430074, China. E-mail: xiegy@scuec.edu.cn

${ }^{b}$ Key Laboratory of Optoelectronic Chemical Materials and Devices, Ministry of Education, School of Chemical and Environmental Engineering, Jianghan University, Wuhan 430056, China

$\dagger$ Electronic supplementary information (ESI) available. CCDC 1587147 and 1587146 contain the supplementary crystallographic data for $\mathbf{L}_{2}$ and $\mathbf{T i}^{2} \mathbf{L}_{2}$. For ESI and crystallographic data in CIF or other electronic format see DOI: 10.1039/c8ra00071a

$\ddagger$ These authors contributed equally to this work.
}

industrial applications. The discovery of single-site group 4 metallocene catalysts is considered one of the most significant breakthroughs after the discovery of Ziegler-Natta catalysts. ${ }^{1}$ Thereafter, single-site non-metallocene catalytic systems, including early and late transition metals catalysts, are thought of as another significant breakthrough, since they can provide novel olefin-based materials with superior activity and greater control over polymer microstructures. ${ }^{2,3}$

Of the non-metallocene candidates, the group 4 nonmetallocene complexes with bidentate anionic $[\mathrm{N}, \mathrm{O}]$ chelate ligands, which was first reported in $1995,{ }^{4}$ have been the focus of attention. A great variety of [N, O] chelate complexes have been reported, among which the most prominent were the group 4 bis(phenoxyimine) ligated complexes (A, Chart 1) reported firstly by Floriani et al. in $1995 .{ }^{5}$ Fujita et al. ${ }^{6}$ and Coates et al. ${ }^{7}$ further developed these ligands and reported some new complexes that are excellent for olefin polymerization including 


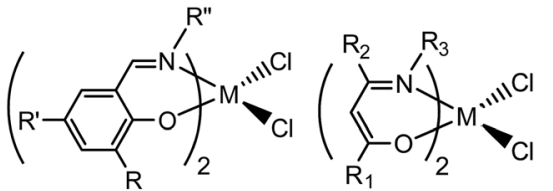

A

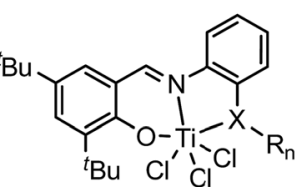

C<smiles></smiles>

D

Chart 1 Some typical mononuclear titanium complexes.

ethylene living polymerization, highly syndiospecific propylene living polymerization, living copolymerization of ethylene with $\alpha$-olefin, and the synthesis of functional and block copolymers of propylene. However, very few successful phenoxyimine catalysts have been reported that effectively catalyze random copolymerization of ethylene and other olefins due to the low comonomer incorporation ratio. The group 4 transition metal complexes based on bis( $\beta$-carbonylenamine) ligands (B, Chart 1) were another group of widely-researched ethylene (co)polymerization precatalysts containing $[\mathrm{N}, \mathrm{O}]$ chelate ligands. ${ }^{\mathbf{4}, \mathbf{8}}$

To further improve the catalytic performances of the bidentate anionic $[\mathrm{N}, \mathrm{O}]$ chelated complexes towards ethylene (co) polymerization, Tang and coworkers have developed a series of mono-ligated tridentate $[\mathrm{ONX}] \mathrm{TiCl}_{3}$ complexes $(\mathrm{X}=\mathrm{O}, \mathrm{S}$, Se, and $\mathrm{P}$ ) based on either salicylaldiminato or $\beta$-carbonylenamine backbone by introducing some sidearms with pendantcoordination heteroatom groups (C and D, Chart 1), ${ }^{9}$ which exhibited better catalytic performances due to the tuning of the electronic and steric properties of the active species by the sidearm. These complexes were especially effective for ethylene copolymerization with $\alpha$-olefins, cycloolefins or polar monomers, due partially to the less crowded coordination sphere. Furthermore, they could be prepared in one step by simply mixing the tridentate ligands and titanium tetrachloride, without the need to deprotonate the ligands in advance.

More recently, there have also been growing interests in biand multi-nuclear olefin polymerization catalysts, ${ }^{3 a-d, 10-13}$ which showed that introducing a proximate metal center could significantly enhance catalytic properties as compared with the mononuclear analogue due to the creation of high local reagent concentrations, conformationally advantageous active-sitesubstrate proximities, as well as multicenter directed covalent and noncovalent interactions. Most of these works were focused on metallocene and late transition metal complexes, while early transition non-metallocene binuclear complexes have rarely been reported. Marks' group reported a class of naphthoylimine-ligated early transition bimetallic catalysts (E, Chart 2) with moderate activity $\left(\sim 10^{4} \mathrm{~g} \mathrm{~mol}^{-1} \mathrm{~h}^{-1} \mathrm{~atm}^{-1}\right)$ and higher comonomer incorporation ratios compared to the mononuclear analogue due to nuclearity and cooperativity effects in binuclear catalysts. ${ }^{10 c, d} \mathrm{Ma}$ and coworkers lately described a bidentate salicylaldimine heteroligated binuclear

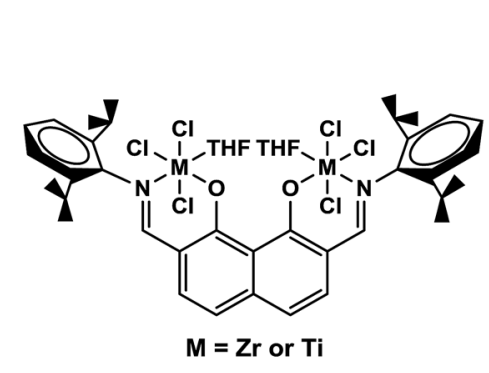

E

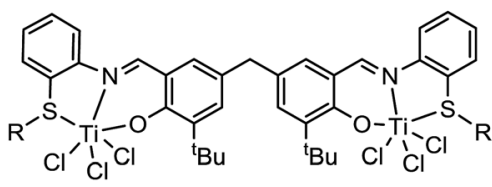

G

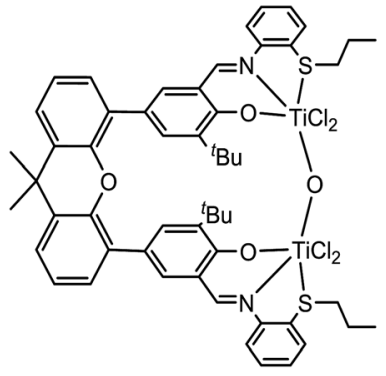

H

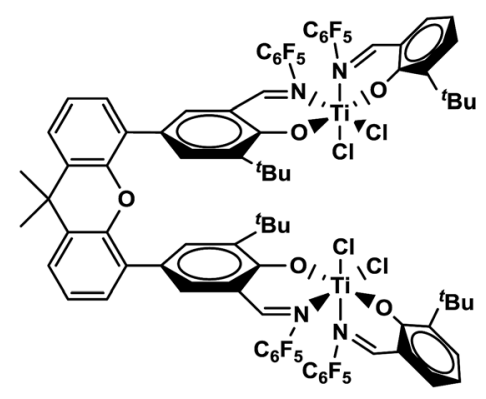

F

Chart 2 Non-metallocene binuclear titanium complexes. 
titanium catalyst (F, Chart 2) with high activity and higher ethylene/1,5-hexadiene copolymerization capability than that of its mononuclear counterpart. ${ }^{13}$

Recently we have been committed to developing some novel early and late transition non-metallocene catalysts based on tuning the coordination environment of the active species with electronic and/or steric effects of the substituents. ${ }^{\mathbf{1 4}}$ In view of the advantage of the less crowded coordination sphere of tridentate ligands and the cooperative effect of binuclear complexes, we have designed a number of binuclear titanium catalysts with methylene- or xanthene-bridged bis(salicylaldiminato) tridentate ligands ( $\mathbf{G}$ and $\mathbf{H}$, Chart 2) and investigated their catalytic behaviors for ethylene homo- and copolymerization. ${ }^{15}$ Here we describe the synthesis, structure and ethylene (co)polymerization behaviors of a series of novel phenyl-bridged bis- $\beta$-carbonylenamine $\left[\mathrm{O}^{-} \mathrm{NS}^{\mathrm{R}}\right](\mathrm{R}=$ alkyl or phenyl $)$ tridentate binuclear titanium complexes $\mathbf{T i}^{2} \mathbf{L}_{\mathbf{1}}-\mathbf{T i}^{\mathbf{2}} \mathbf{L}_{\mathbf{5}}$ (Chart 2).

\section{Results and discussion}

\subsection{Synthesis and structure of ligands and binuclear Ti complexes}

The synthetic routes for the ligands $\mathbf{L}_{\mathbf{1}}-\mathbf{L}_{\mathbf{6}}$ and the corresponding complexes $\mathbf{T i}^{\mathbf{2}} \mathbf{L}_{\mathbf{1}}-\mathbf{T i}^{2} \mathbf{L}_{\mathbf{5}}$ and $\mathbf{T i L _ { 6 }}$ were shown in Scheme 1 and 2 .
Firstly, 1,1'-(1,3-phenylene)-bis(4,4-dimethylpentane-1,3-dione) (2) and 4,4-dimethyl-1-phenylpentane-1,3-dione (4) were synthesized according to the work of L. F. Lindoy's group ${ }^{\mathbf{1 6}}$ through Claisen condensation of dimethyl isophthalate or methyl benzoate with pinacolone deprotonated by sodium amide, which then reacted with alkylthio anilines to obtain bis- and mono- $\beta$ carbonylenamine [ONS] tridentate ligands $\mathbf{L}_{\mathbf{1}}-\mathbf{L}_{\mathbf{6}}$ in $68-83 \%$ yields. Finally, binuclear $\mathrm{Ti}$ complexes $\mathbf{T i}^{2} \mathbf{L}_{\mathbf{1}}-\mathbf{T i}^{2} \mathbf{L}_{\mathbf{5}}$ and mononuclear counterpart $\mathbf{T i L}_{\mathbf{6}}$ were prepared by reacting the ligands $\mathbf{L}_{\mathbf{1}}-\mathbf{L}_{\mathbf{6}}$ directly with excess $\mathrm{TiCl}_{4}$ according to Tang's ${ }^{9}$ and our previous works. ${ }^{15}$ The structures of the free ligands and the corresponding bi- and mono-nuclear Ti complexes were characterized by ${ }^{1} \mathrm{H}$ NMR, ${ }^{13} \mathrm{C}$ NMR, FT IR and elemental analysis. Notable changes of the ${ }^{1} \mathrm{H}$ NMR spectra were that the $\mathrm{NH}$ resonances of the ligands at $\delta$ 12.05-12.22 ppm disappeared upon forming the Ti complexes.

The molecular structures of ligand $\mathbf{L}_{2}$ and its corresponding Ti complex $\mathbf{T i}^{2} \mathbf{L}_{2}$ were further confirmed by single-crystal X-ray diffraction, as shown in Fig. 1 and 2. The crystal data and details of data collection and refinement are summarized in Table 1, and selected bond lengths and angles are listed in Table 2 .

Two possible pathways existed for the synthesis of ligands $\mathbf{L}_{\mathbf{1}}-\mathbf{L}_{5}$ and complexes $\mathbf{T i}^{2} \mathbf{L}_{\mathbf{1}}-\mathbf{T i}^{2} \mathbf{L}_{\mathbf{5}}$ due to the presence of two different carbonyl groups in phenylene-bridged $\beta$-dione (2), as shown in Scheme 3. In the case that 1-phenylbutane-1,3dione was employed for the preparation of enamine, X-ray

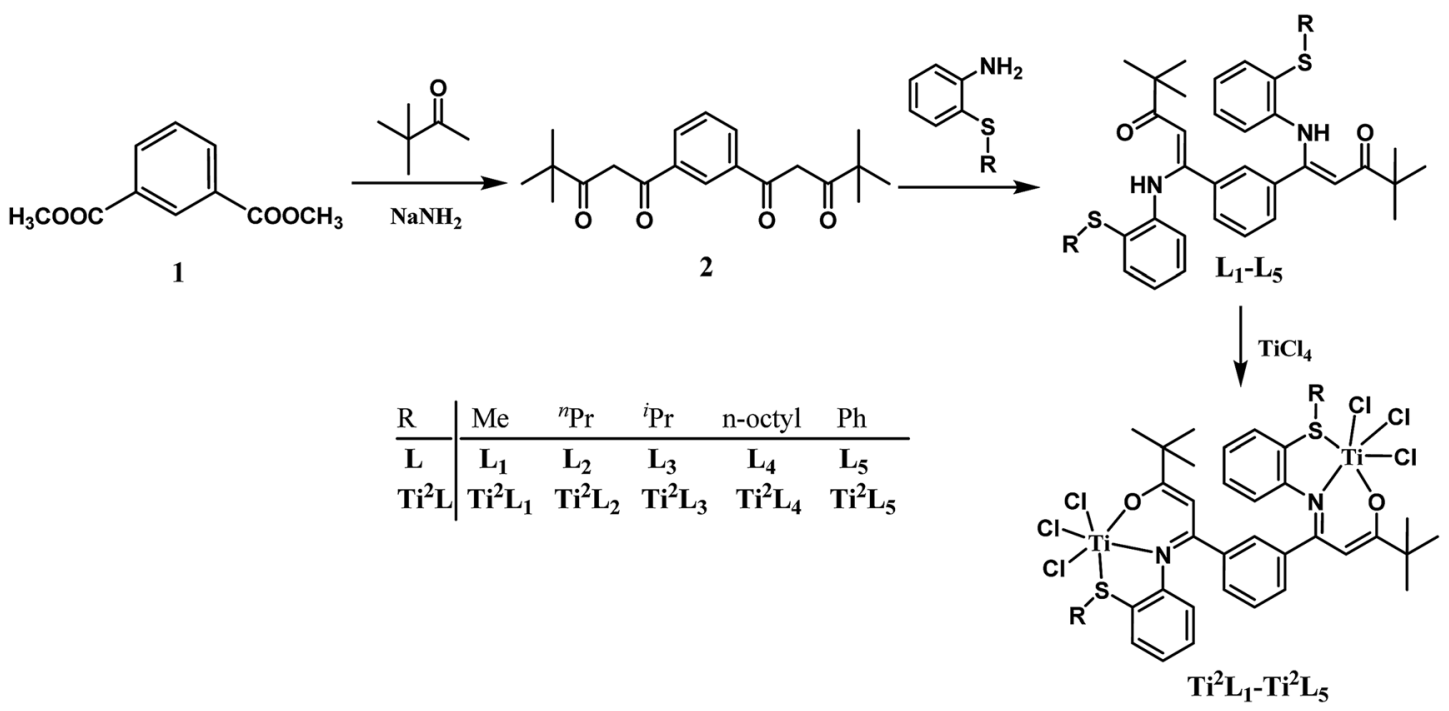

Scheme 1 Synthesis of binuclear Ti complexes $\mathrm{Ti}^{2} \mathrm{~L}_{1}-\mathrm{Ti}^{2} \mathrm{~L}_{5}$.

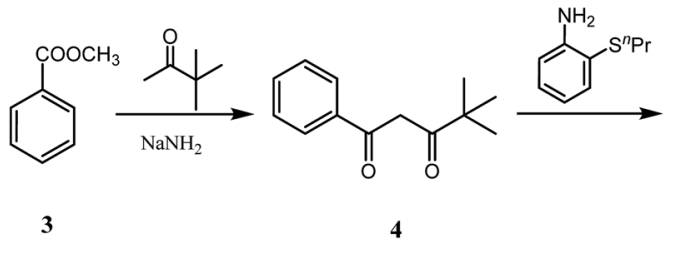<smiles>CCCSc1ccccc1NC(=CC(=O)C(C)(C)C)c1ccccc1</smiles>

Scheme 2 Synthesis of mononuclear Ti complex TiL 6 . 


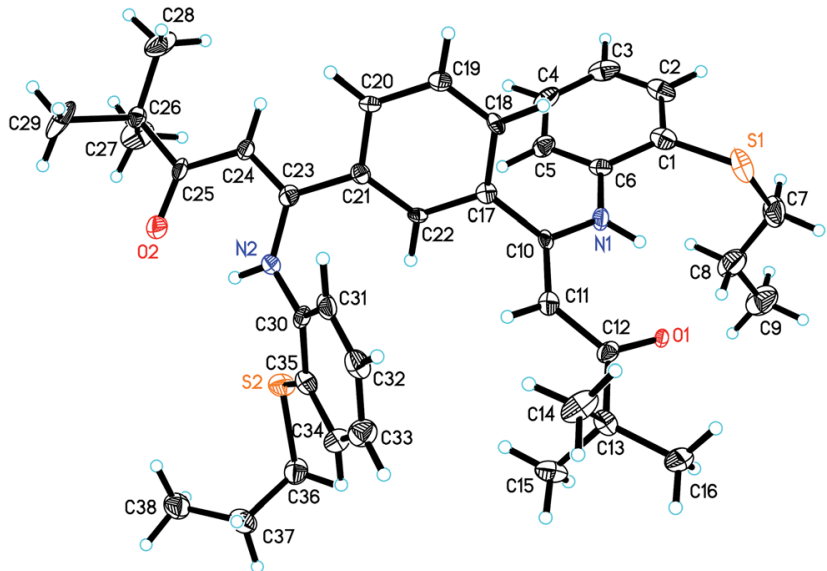

Fig. 1 The crystal structure of ligand $\mathrm{L}_{2}$.

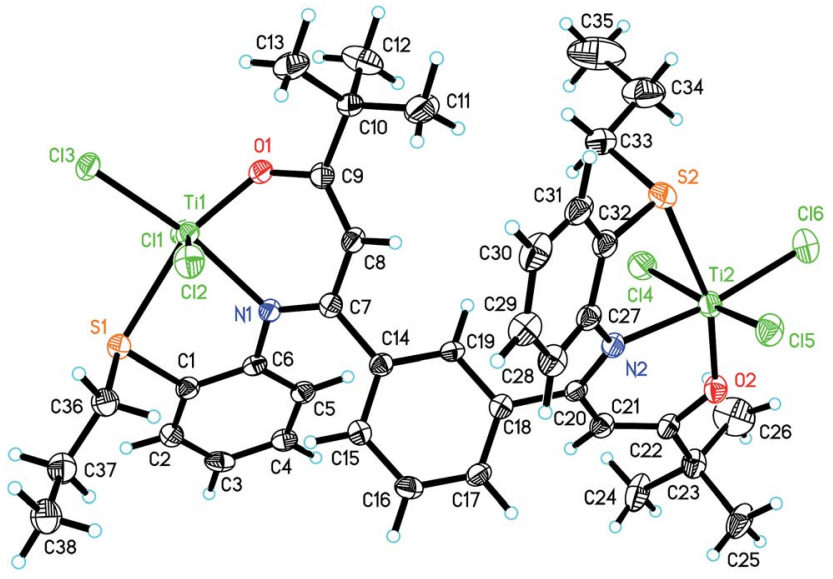

Fig. 2 The crystal structure of complex $\mathrm{Ti}^{2} \mathrm{~L}_{2}$. crystallographic analysis showed that the acetyl group of 1phenylbutane-1,3-dione reacted with amine ( $\mathbf{L}_{7}$, Fig. 3). ${ }^{9 c}$ However, in the case of our bis- $\beta$-carbonylenamine ligands $\mathbf{L}_{\mathbf{1}}-\mathbf{L}_{\mathbf{5}}$, the single-crystal XRD proved that the alkylthio anilines reacted with the carbonyl group adjacent to phenylene group (Path B), not the one next to the ${ }^{t}$ butyl group (Path A), which resulted in far-separated and relatively independent titanium centers in complexes $\mathbf{T i}^{2} \mathbf{L}_{\mathbf{1}}-\mathbf{T i}^{\mathbf{2}} \mathbf{L}_{\mathbf{5}}$ and would profoundly influence their catalytic performances for ethylene (co)polymerization.

From Fig. 1, it can be seen that in $\mathbf{L}_{2}$, the N1-C10-C11-C12$\mathrm{O} 1$ and $\mathrm{N} 2-\mathrm{C} 23-\mathrm{C} 24-\mathrm{C} 25-\mathrm{O} 2$ are almost coplanar, which further formed two six-member rings via intramolecular hydrogen bonds between $\mathrm{H}$ and $\mathrm{O} 1$ or $\mathrm{O} 2$. The $\mathrm{O} 1-\mathrm{C} 12$ and O2-C25 bond lengths are 1.251 and $1.255 \AA$, respectively, a little longer than the typical $\mathrm{C}=\mathrm{O}$ double bond but much shorter than $\mathrm{C}-\mathrm{O}$ single bond. The $\mathrm{C} 10-\mathrm{N} 1$ and $\mathrm{C} 23-\mathrm{N} 2$ bond distances are 1.376(7) and 1.370(7) $\AA$, respectively, showing clearly that the $\mathrm{C}-\mathrm{N}$ bonds are single bonds. Thus, the ligand $\mathbf{L}_{2}$ exists in $\beta$-carbonylenamine form. The $\mathrm{C} 11-\mathrm{C} 12$ and $\mathrm{C} 24-\mathrm{C} 25$ bond lengths are $1.444(8)$ and $1.441(8) \AA$, respectively, and the C10-C11 and C23-C24 bond lengths are 1.400(8) and 1.379(8) $\mathrm{A}$, respectively, which are all between $\mathrm{C}-\mathrm{C}$ single bond $(1.54 \AA)$ and $\mathrm{C}=\mathrm{C}$ double bond $(1.34 \AA)$ and show a certain extent of delocalization of the double bonds. Furthermore, the distances of the corresponding bonds in two $\beta$-carbonylenamine units are a little different, which would provide different coordination environments for the two titanium metal centers.

As revealed by XRD analysis, complex $\mathbf{T i}^{2} \mathbf{L}_{2}$ adopted a distorted octahedral configuration with each titanium coordinated with an oxygen, a nitrogen, a sulfur and three chlorine atoms. The O1-C9 and O2-C22 bond lengths were 1.338(6) and 1.322(6) $\AA$, respectively, which were appreciably longer than the corresponding $\mathrm{O} 1-\mathrm{C} 12$ and $\mathrm{O} 2-\mathrm{C} 25$ bonds in the ligand. Compared with the $\mathrm{C} 11-\mathrm{C} 12$ and $\mathrm{C} 24-\mathrm{C} 25$ bonds in ligand, the corresponding C9-C8 and C22-C21 bond lengths (1.351(7), 1.367(7)

Table 1 The crystal data and structure refinement for ligand $L_{2}$ and complex $\mathrm{Ti}^{2} \mathrm{~L}_{2}$

\begin{tabular}{|c|c|c|}
\hline & $\mathbf{L}_{2}$ & $\mathbf{T i}^{2} \mathbf{L}_{2}$ \\
\hline Empirical formula & $\mathrm{C}_{38} \mathrm{H}_{48} \mathrm{~N}_{2} \mathrm{O}_{2} \mathrm{~S}_{2}$ & $\mathrm{C}_{38} \mathrm{H}_{46} \mathrm{Cl}_{6} \mathrm{~N}_{2} \mathrm{O}_{2} \mathrm{~S}_{2} \mathrm{Ti}_{2}$ \\
\hline Formula weight & 628.90 & 935.39 \\
\hline Crystal system & Monoclinic & Monoclinic \\
\hline Space group & $P 12_{1} / c 1$ & $P 2_{1} / c$ \\
\hline$a(\AA)$ & $14.149(5)$ & $18.572(3)$ \\
\hline$\alpha\left(^{\circ}\right)$ & $90^{\circ}$ & $90^{\circ}$ \\
\hline$\beta\left(^{\circ}\right)$ & $96.710(6)^{\circ}$ & $108.118(3)^{\circ}$ \\
\hline$\gamma\left({ }^{\circ}\right)$ & $90^{\circ}$ & $90^{\circ}$ \\
\hline$V\left(\AA^{3}\right)$ & $3487.7(19)$ & $4721.4(14)$ \\
\hline$Z$ & 4 & 4 \\
\hline Density $\left(\mathrm{Mg} \mathrm{m}^{-3}\right)$ & 1.198 & 1.316 \\
\hline Final $R$ indices $[I>2 \sigma(I)]$ & $R_{1}=0.0916, \mathrm{w} R_{2}=0.2043$ & $R_{1}=0.0705, \mathrm{w} R_{2}=0.1858$ \\
\hline
\end{tabular}


Table 2 Selected bond lengths $(\AA)$ and bond angles $\left(^{\circ}\right)$ for ligand $L_{2}$ and complex $\operatorname{Ti}^{2} L_{2}$

\begin{tabular}{|c|c|c|c|c|c|}
\hline \multicolumn{2}{|l|}{$\mathbf{L}_{2}$} & \multicolumn{4}{|l|}{$\mathbf{T i}^{2} \mathbf{L}_{2}$} \\
\hline$S(1)-C(1)$ & $1.769(7)$ & $S(1)-C(1)$ & $1.780(5)$ & $\mathrm{O}(1)-\mathrm{Ti}(1)-\mathrm{N}(1)$ & $84.26(15)$ \\
\hline $\mathrm{S}(1)-\mathrm{C}(7)$ & $1.845(8)$ & $S(1)-C(36)$ & $1.819(6)$ & $\mathrm{O}(1)-\mathrm{Ti}(1)-\mathrm{Cl}(3)$ & $104.94(12)$ \\
\hline$S(2)-C(36)$ & $1.831(7)$ & $S(2)-C(33)$ & $1.826(6)$ & $\mathrm{O}(1)-\mathrm{Ti}(1)-\mathrm{Cl}(2)$ & $92.15(13)$ \\
\hline $\mathrm{O}(1)-\mathrm{C}(12)$ & $1.251(7)$ & $\mathrm{O}(1)-\mathrm{C}(9)$ & $1.338(6)$ & $\mathrm{N}(1)-\mathrm{Ti}(1)-\mathrm{Cl}(2)$ & $86.38(12)$ \\
\hline $\mathrm{O}(2)-\mathrm{C}(25)$ & $1.225(7)$ & $\mathrm{O}(2)-\mathrm{C}(22)$ & $1.322(6)$ & $\mathrm{Cl}(3)-\mathrm{Ti}(1)-\mathrm{Cl}(2)$ & $92.34(6)$ \\
\hline$C(10)-C(11)$ & $1.400(8)$ & $C(7)-C(8)$ & $1.447(7)$ & $\mathrm{Cl}(3)-\mathrm{Ti}(1)-\mathrm{Cl}(1)$ & $93.22(6)$ \\
\hline $\mathrm{C}(11)-\mathrm{C}(12)$ & $1.444(8)$ & $C(8)-C(9)$ & $1.351(7)$ & $\mathrm{Cl}(2)-\mathrm{Ti}(1)-\mathrm{Cl}(1)$ & $168.04(7)$ \\
\hline $\mathrm{C}(23)-\mathrm{C}(24)$ & $1.379(8)$ & $C(20)-C(21)$ & $1.447(7)$ & $\mathrm{O}(1)-\mathrm{Ti}(1)-\mathrm{S}(1)$ & $161.35(12)$ \\
\hline \multirow[t]{15}{*}{$C(24)-C(25)$} & $1.441(8)$ & $C(21)-C(22)$ & $1.367(7)$ & $\mathrm{N}(1)-\mathrm{Ti}(1)-\mathrm{S}(1)$ & $77.11(11)$ \\
\hline & & $\operatorname{Ti}(1)-O(1)$ & $1.825(3)$ & $\mathrm{Cl}(3)-\mathrm{Ti}(1)-\mathrm{S}(1)$ & $93.71(6)$ \\
\hline & & $\mathrm{Ti}(1)-\mathrm{N}(1)$ & $2.172(4)$ & $\mathrm{Cl}(2)-\mathrm{Ti}(1)-\mathrm{S}(1)$ & $87.51(6)$ \\
\hline & & & & $\mathrm{O}(2)-\mathrm{Ti}(2)-\mathrm{Cl}(5)$ & $99.81(13)$ \\
\hline & & & & $\mathrm{N}(2)-\mathrm{Ti}(2)-\mathrm{Cl}(5)$ & $87.78(12)$ \\
\hline & & & & $\mathrm{Cl}(6)-\mathrm{Ti}(2)-\mathrm{Cl}(5)$ & $90.35(7)$ \\
\hline & & & & $\mathrm{O}(2)-\mathrm{Ti}(2)-\mathrm{Cl}(4)$ & $91.01(13)$ \\
\hline & & & & $\mathrm{N}(2)-\mathrm{Ti}(2)-\mathrm{Cl}(4)$ & $86.13(12)$ \\
\hline & & & & $\mathrm{Cl}(6)-\mathrm{Ti}(2)-\mathrm{Cl}(4)$ & $93.72(7)$ \\
\hline & & & & $\mathrm{Cl}(5)-\mathrm{Ti}(2)-\mathrm{Cl}(4)$ & $167.04(7)$ \\
\hline & & & & $\mathrm{O}(2)-\mathrm{Ti}(2)-\mathrm{S}(2)$ & $161.71(12)$ \\
\hline & & & & $\mathrm{N}(2)-\mathrm{Ti}(2)-\mathrm{S}(2)$ & $77.18(12)$ \\
\hline & & & & $\mathrm{Cl}(6)-\mathrm{Ti}(2)-\mathrm{S}(2)$ & $93.03(6)$ \\
\hline & & & & $\mathrm{Cl}(5)-\mathrm{Ti}(2)-\mathrm{S}(2)$ & $82.01(6)$ \\
\hline & & & & $\mathrm{Cl}(4)-\mathrm{Ti}(2)-\mathrm{S}(2)$ & $85.48(7)$ \\
\hline
\end{tabular}

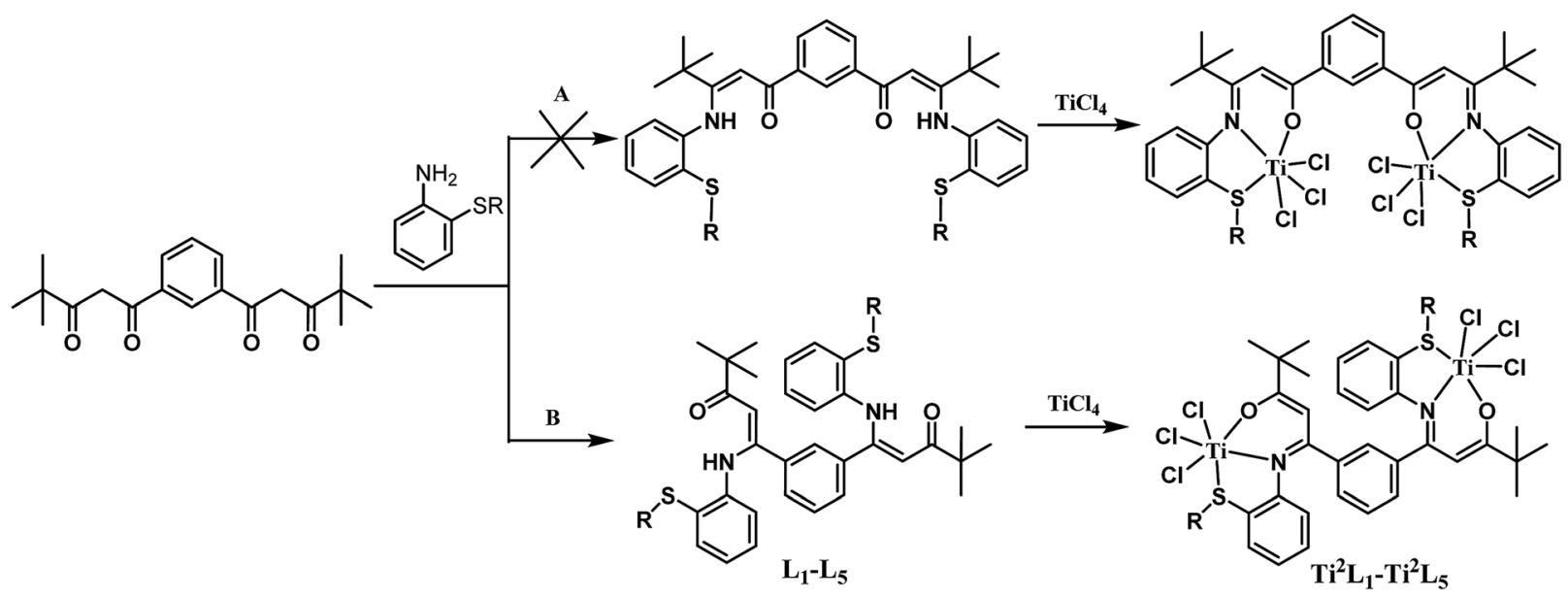

Scheme 3 Two possible pathways for the synthesis of ligands $L_{1}-L_{5}$ and complexes $T^{2} L_{1}-T i^{2} L_{5}$.

A) were significantly shorter and clearly showed some double bond characteristic. Furthermore, compared with the $\mathrm{C}-\mathrm{C}$ and $\mathrm{C}-\mathrm{N}$ bonds in ligand, the corresponding $\mathrm{C} 7-\mathrm{C} 8$ and $\mathrm{C} 20-\mathrm{C} 21$ bonds were elongated, and the $\mathrm{C} 7-\mathrm{N} 1$ and $\mathrm{C} 20-\mathrm{N} 2$ were shortened, all of which demonstrated that the ligand has converted to $\beta$-imino enol form after coordinating with titanium.

The bond angle sum of O1-Ti1-N1 $\left(84.26^{\circ}\right)$, N1-Ti1-S1 $\left(77.11^{\circ}\right)$, $\mathrm{S} 1-\mathrm{Ti} 1-\mathrm{Cl} 3\left(93.71^{\circ}\right)$ and $\mathrm{Cl} 3-\mathrm{Ti} 1-\mathrm{O} 1\left(104.94^{\circ}\right)$ is nearly $360^{\circ}$, so the N1, O1, S1, Cl3 and Ti1 are almost coplanar. The same is true for $\mathrm{N} 2, \mathrm{O} 2, \mathrm{~S} 2, \mathrm{Cl} 6$ and Ti2. The three chlorine atoms on Ti1 are in a mer disposition with the bond angles of Cl1-Ti-Cl3, Cl2-Ti-Cl3 and Cl1-Ti-Cl2 of 93.22(6), 92.34(6) and $168.04(7)^{\circ}$, respectively, which is favorable for the olefin coordination and insertion. The Ti1-O1, Ti1-N1 and Ti1-S1 distances and the average $\mathrm{Ti}-\mathrm{Cl}$ distance are close to the mononuclear $\beta$-carbonylenamine-derived $\left[\mathrm{O}^{-} \mathrm{NS}\right] \mathrm{TiCl}_{3}$ complexes 


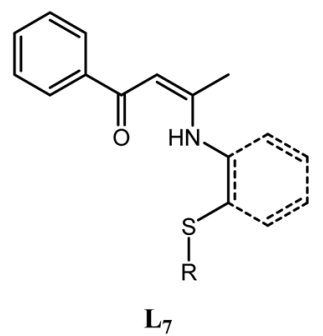

Fig. 3 Mono- $\beta$-carbonylenamine ligand $L_{7}$ derived from 1-phenylbutane-1,3-dione.

reported by Tang's group. The bond angle sum of C1-S1-C36 $\left(103.7(3)^{\circ}\right), \mathrm{C} 1-\mathrm{S} 1-\mathrm{Ti} 1\left(95.87(17)^{\circ}\right)$, and C36-S1-Ti1 $\left(112.2(2)^{\circ}\right)$ is $311.77^{\circ}$, suggesting that the $\mathrm{S}$ atom in $\mathbf{T i}^{2} \mathbf{L}_{2}$ is $\mathrm{sp}^{3}$-hybridized. The dihedral angel between N1-C7-C8-C9-O1 and N1-Ti1-O1 or the $\mathrm{C} 14-\mathrm{C} 15-\mathrm{C} 16-\mathrm{C} 17-\mathrm{C} 18-\mathrm{C} 19$ ring are $32.98^{\circ}$ and $42.35^{\circ}$, and the dihedral angel between N2-C20-C21-C22-O2 and N2-Ti2$\mathrm{O} 2$ or the C14-C15-C16-C17-C18-C19 ring are $29.47^{\circ}$ and $59.08^{\circ}$, respectively.

\subsection{Ethylene polymerization}

We investigated the catalytic performances of binuclear complexes $\mathbf{T i}^{2} \mathbf{L}_{\mathbf{1}}-\mathbf{T i}^{\mathbf{2}} \mathbf{L}_{\mathbf{5}}$ towards ethylene polymerization under activation of MMAO, with the mononuclear analogue $\mathbf{T i L}_{\mathbf{6}}$ for comparison, and the results were listed in Table 3.

In general, these binuclear complexes exhibited very high activity (over $10^{6} \mathrm{~g} \mathrm{~mol}^{-1} \mathrm{~h}^{-1} \mathrm{~atm}^{-1}$ ) under suitable conditions, producing typical high-density polyethylene. The polymerization conditions such as reaction temperatures and $\mathrm{Al} / \mathrm{Ti}$ molar ratios exerted great influence upon catalytic activity and polymer properties.

Firstly, we used $\mathbf{T i}^{2} \mathbf{L}_{2}$ as catalyst precursor and explored the influence of polymerization temperature at 1 atm ethylene pressure with $\mathrm{Al} / \mathrm{Ti}$ ratio fixed at 1000 . When the reaction temperature was increased from 30 to $70^{\circ} \mathrm{C}$, the activity increased gradually to a maximum at $50{ }^{\circ} \mathrm{C}$ and then decreased slightly. The highest activity reached $1.68 \times 10^{6} \mathrm{~g} \mathrm{~mol}(\mathrm{Ti})^{-1} \mathrm{~h}^{-1} \mathrm{~atm}^{-1}$ at $50{ }^{\circ} \mathrm{C}$ (entry

Table 3 The results of ethylene polymerization catalyzed by binuclear Ti complexes ${ }^{a}$

\begin{tabular}{llllllll}
\hline Entry & Cat. & Al/Ti & Temp $\left({ }^{\circ} \mathbf{C}\right)$ & PE $(\mathrm{g})$ & Act. $^{b}$ & $M_{\mathrm{w}}{ }^{c}$ & $M_{\mathrm{w}} / M_{\mathrm{n}}$ \\
\hline 1 & $\mathbf{T i}^{2} \mathbf{L}_{\mathbf{2}}$ & $1000: 1$ & 30 & 0.3200 & 0.96 & & \\
2 & $\mathbf{T i}^{2} \mathbf{L}_{\mathbf{2}}$ & $1000: 1$ & 50 & 0.5608 & 1.68 & 3.62 & 3.65 \\
3 & $\mathbf{T i}^{2} \mathbf{L}_{\mathbf{2}}$ & $1000: 1$ & 70 & 0.3029 & 0.91 & & \\
4 & $\mathbf{T i}^{2} \mathbf{L}_{\mathbf{2}}$ & $500: 1$ & 50 & 0.3578 & 1.07 & & \\
5 & $\mathbf{T i}^{2} \mathbf{L}_{\mathbf{2}}$ & $1500: 1$ & 50 & 0.3813 & 1.14 & & \\
6 & $\mathbf{T i}^{2} \mathbf{L}_{\mathbf{2}}$ & $2000: 1$ & 50 & 0.3342 & 1.00 & & \\
7 & $\mathbf{T i}^{2} \mathbf{L}_{\mathbf{1}}$ & $1000: 1$ & 50 & 0.4421 & 1.33 & 4.53 & 2.82 \\
8 & $\mathbf{T i}^{2} \mathbf{L}_{\mathbf{3}}$ & $1000: 1$ & 50 & 0.3634 & 1.09 & 4.95 & 4.30 \\
9 & $\mathbf{T i}^{2} \mathbf{L}_{\mathbf{4}}$ & $1000: 1$ & 50 & 0.2736 & 0.82 & 4.47 & 4.08 \\
10 & $\mathbf{T i}^{2} \mathbf{L}_{\mathbf{5}}$ & $1000: 1$ & 50 & 0.6451 & 1.94 & 14.82 & 2.65 \\
$11^{d}$ & $\mathbf{T i L}_{\mathbf{6}}$ & $1000: 1$ & 50 & 0.5159 & 1.55 & 5.24 & 2.59 \\
$12^{d}$ & $\mathbf{T i L}_{\mathbf{6}}$ & $1000: 1$ & 70 & 0.1415 & 0.42 & &
\end{tabular}

${ }^{a}$ Toluene $30 \mathrm{ml}, 2 \mu \mathrm{mol}$ of catalyst, 1 atm ethylene pressure, reaction time $5 \mathrm{~min} .{ }^{b}$ Activity, $10^{6} \mathrm{~g} \mathrm{~mol}(\mathrm{Ti})^{-1} \mathrm{~h}^{-1} \mathrm{~atm}^{-1} \cdot{ }^{c} 10^{4} \mathrm{~g} \mathrm{~mol}^{-1}$, determined by GPC using polystyrene standard. ${ }^{d} 4 \mu \mathrm{mol}$ of catalyst.
2, Table 3), which was similar to that catalyzed by the mononuclear analogue TiL $_{6} / \mathrm{MMAO}\left(1.55 \times 10^{6} \mathrm{~g} \mathrm{~mol}(\mathrm{Ti})^{-1} \mathrm{~h}^{-1} \mathrm{~atm}^{-1}\right.$, entry 10 in Table 3$)$. However, the binuclear complex appeared more stable at elevated temperature compared with the mononuclear $\mathbf{T i L}_{6}$. At $70{ }^{\circ} \mathrm{C}$, the activity of $\mathbf{T i}^{2} \mathbf{L}_{2} / \mathrm{MMAO}$ was still of 9.1 $\times 10^{5} \mathrm{~g} \mathrm{~mol}(\mathrm{Ti})^{-1} \mathrm{~h}^{-1} \mathrm{~atm}^{-1}$, which was more than twice that of $\mathrm{TiL}_{6} / \mathrm{MMAO}$ at the same temperature.

Both bi- and mono-nuclear titanium catalysts catalyzed ethylene polymerization to produce polyethylene with over $10^{4} \mathrm{~g}$ $\mathrm{mol}^{-1}$ of molecular weight $\left(M_{\mathrm{w}}\right)$. The molecular weight distribution $\left(M_{\mathrm{w}} / M_{\mathrm{n}}\right)$ of polyethylene produced by $\mathbf{T i L}_{6} /$ MMAO was only 2.59, which was typical of single active center; however the polymer obtained with $\mathbf{T i}^{2} \mathbf{L}_{\mathbf{2}} / \mathbf{M M A O}$ exhibited much wider polydispersity (3.65), indicating that two active centers may have formed, consistent with the asymmetrical crystal structure of the binuclear complex.

The catalytic activity of the binuclear catalyst was less sensitive to the $\mathrm{Al} / \mathrm{Ti}$ molar ratio. The catalyst exhibited high activity of over $10^{6} \mathrm{~g}$ mol $(\mathrm{Ti})^{-1} \mathrm{~h}^{-1} \mathrm{~atm}^{-1}$ even at a low $\mathrm{Al} / \mathrm{Ti}$ ratio of 500, and with $\mathrm{Al} / \mathrm{Ti}$ ratio increased from 500 to 2000 , the activity increased slightly to a maximum at an $\mathrm{Al} / \mathrm{Ti}$ ratio of 1000 and then slowly decreased.

The catalytic performances of the binuclear complexes bearing different alkylthio and phenylthio sidearms were also compared. The steric hindrance of substituents on sulfur atom influenced both the catalytic activity and molecular weight of the resulting polyethylene. Take $\mathbf{T i}^{2} \mathbf{L}_{2}$ and $\mathbf{T i}^{2} \mathbf{L}_{3}$ for example (entry 2 vs. 8, Table 3), as the sidearm $n$-propylthio changed to bulkier iso-propylthio, the catalytic activity decreased from 1.68 to $1.09 \times 10^{6} \mathrm{~g}$ mol $(\mathrm{Ti})^{-1} \mathrm{~h}^{-1}$ atm $^{-1}$, while the molecular weight increased from 3.62 to $4.95 \times 10^{4} \mathrm{~g} \mathrm{~mol}^{-1}$. The complex $\mathbf{T i}^{2} \mathbf{L}_{5}$ which bears the bulkier phenylthio sidearm produced polyethylene with still-higher molecular weight than those with the alkylthio sidearms (entry 10 vs. 2, 7-9, Table 3). Similar influences of steric hindrance have also been observed in mononuclear titanium complexes. ${ }^{9 b}$

The influence of substituents was also investigated by varying the length of the linear alkylthio sidearms. Unlike the mononuclear analogues reported by Tang's group ${ }^{9 c}$ and the methylene-bridged salicylaldiminato binuclear titanium complexes reported by $\mathrm{us}^{\mathbf{1 5} a}$ previously, the catalytic activity decreased from 1.68 to $0.82 \times 10^{6} \mathrm{~g} \mathrm{~mol}(\mathrm{Ti})^{-1} \mathrm{~h}^{-1}$ atm $^{-1}$ (entry 2 vs. 9, Table 3) when the substituent on sulfur atom was changed from $n$-propyl group to n-octyl group. However, replacement of $n$-propyl group with methyl group also decreased the activity slightly, due probably to the weaker solubility of $\mathbf{T i}^{2} \mathbf{L}_{\mathbf{1}}$ (entry 2 vs. 7, Table 3). With the increase of the alkyl chain length of the side group on sulfur atom, the molecular weight distribution of obtained PE increased gradually, while the molecular weight remained almost unchanged. The GPC curves for the PE samples were shown in Fig. 4.

\subsection{Ethylene copolymerization with $\alpha$-olefins}

We also explored the catalytic behaviors of these binuclear complexes towards ethylene copolymerization with $\alpha$-olefins, and the results were shown in Table 4 . 


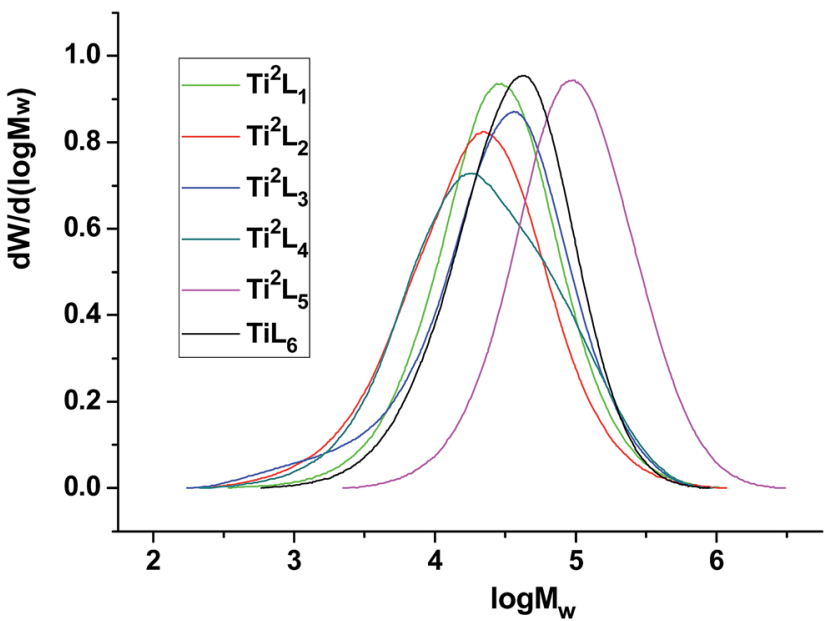

Fig. 4 GPC curves for the PE samples obtained with bi- and mononuclear Ti complexes.

All of these complexes showed extremely high activity for the copolymerization of ethylene and $\alpha$-olefins, which were $2-5$ times higher than the homopolymerization activity (Table 3). The products were branched polyethylene as revealed by their much reduced melting points and the high temperature ${ }^{13} \mathrm{C}$ NMR spectra. The 1-hexene incorporation ratio in the copolymer could be flexibly tuned by the initial feed of $\alpha$-olefin commoners and catalyst structures. It should be noted that these bis- $\beta$-carbonylenamine-derived binuclear titanium complexes showed much higher copolymerization activity and $\alpha$-olefin incorporation ratio compared with the methylenebridged bis-salicylaldiminato binuclear titanium complexes reported by us before under similar conditions. ${ }^{15 a}$

The influences of 1-hexene feeds upon catalytic performances were investigated with $\mathbf{T i}^{2} \mathbf{L}_{\mathbf{2}} / \mathrm{MMAO}$ as a representative. As the feed of 1-hexene was increased from 6 to $36 \mathrm{mmol}$, the 1-hexene incorporation ratio increased sharply from 5.1 to $19.1 \mathrm{~mol} \%$ (calculated from the ${ }^{13} \mathrm{C}$ NMR spectra, entry $1-4$, Table 4 ), while the copolymerization activity increased from $2.04 \times 10^{6} \mathrm{~g} \mathrm{~mol}$
$(\mathrm{Ti})^{-1} \mathrm{~h}^{-1} \mathrm{~atm}^{-1}$ to a maximum of $5.59 \times 10^{6} \mathrm{~g} \mathrm{~mol}(\mathrm{Ti})^{-1} \mathrm{~h}^{-1}$ atm $^{-1}$ at $24 \mathrm{mmol}$ of 1-hexene, and then decreased slightly to $\left.4.23 \times 10^{6} \mathrm{~g} \mathrm{~mol} \mathrm{(Ti)}\right)^{-1} \mathrm{~h}^{-1} \mathrm{~atm}^{-1}$ at $36 \mathrm{mmol}$. It appeared that within a certain range the activity of the binuclear Ti complex increased apparently with the increase of 1-hexene concentration, showing positive "comonomer effect".

The structure of binuclear titanium complexes also affected their catalytic performances for ethylene/1-hexene copolymerization. Under the same conditions, the increase of steric hindrance of the substituents on sulfur atom reduced the copolymerization activity and 1-hexene incorporation ratio, but increased the molecular weight of obtained copolymers (entry 2 vs. 6, n-propyl vs. iso-propyl, entry 2 vs. 7, n-propyl vs. n-octyl, Table 4). Furthermore, replacement of $n$-propyl group with smaller sized methyl group enhanced significantly the 1-hexene incorporation ratio from 11.3 to $18.3 \mathrm{~mol} \%$ and decreased the molecular weight from 8.42 to $3.42 \times 10^{4} \mathrm{~g} \mathrm{~mol}^{-1}$ (entry 2 vs. 5 , Table 4). However, replacement of alkyl group with phenyl group on sulfur atom lowered the 1-hexene incorporation ratio (entry 2, 5-7 vs. 8, Table 4), which was in good accord with the salicylaldiminato mononuclear titanium complexes reported by Tang. ${ }^{9}$

The high temperature ${ }^{13} \mathrm{C}$ NMR spectra of copolymers produced by $\mathbf{T i}^{2} \mathbf{L}_{\mathbf{1}}, \mathbf{T i}^{\mathbf{2}} \mathbf{L}_{2}, \mathbf{T i}^{2} \mathbf{L}_{\mathbf{4}}$ and $\mathbf{T i}^{2} \mathbf{L}_{5}$ were shown in Fig. 5 , with the corresponding carbon units marked for different peaks. Variation of branch density can be clearly observed, as demonstrated by the relative peak heights. The GPC curves for the ethylene/1-hexene copolymers obtained with bi- and mononuclear Ti complexes were shown in Fig. 6.

Under the same conditions, complex $\mathbf{T i}^{2} \mathbf{L}_{2}$ demonstrated lower copolymerization activity and 1-hexene incorporation ratio than those of its mononuclear counterpart TiL $_{6}$ (entry $2 v s$. 9, Table 4), probably due to the steric and electronic effects of the altered coordination environment. This type of binuclear titanium complexes showed negligible bimetallic cooperative effects due to the far-separation of the two titanium centers.

The binuclear titanium complex $\mathbf{T i}^{2} \mathbf{L}_{2}$ could also efficiently catalyze ethylene copolymerization with 1-octene or 1-decene, with higher activity but lower comonomer incorporation ratio

Table 4 Copolymerization of ethylene and $\alpha$-olefins catalyzed by binuclear Ti complexes ${ }^{a}$

\begin{tabular}{|c|c|c|c|c|c|c|c|c|}
\hline Entry & Cat. & $\begin{array}{l}\text { Comonomer } \\
(\mathrm{mmol})\end{array}$ & Polymer (g) & Act. ${ }^{b}$ & $T_{\mathrm{m}}^{c}\left({ }^{\circ} \mathrm{C}\right)$ & $M_{\mathrm{w}}{ }^{d}$ & $M_{\mathrm{w}} / M_{\mathrm{n}}$ & $\operatorname{Incorp}^{e}(\mathrm{~mol} \%)$ \\
\hline 1 & $\mathbf{T i}^{2} \mathbf{L}_{2}$ & C6(6) & 0.6807 & 2.04 & 107.0 & & & 5.1 \\
\hline 2 & $\mathbf{T i}^{2} \mathbf{L}_{2}$ & C6(12) & 1.4062 & 4.22 & 94.6 & 8.42 & 3.89 & 11.3 \\
\hline 3 & $\mathbf{T i}^{2} \mathbf{L}_{2}$ & C6(24) & 1.8634 & 5.59 & 84.5 & & & 18.7 \\
\hline 4 & $\mathbf{T i}^{2} \mathbf{L}_{2}$ & C6(36) & 1.4110 & 4.23 & - & & & 19.1 \\
\hline 5 & $\mathbf{T i}^{2} \mathbf{L}_{1}$ & C6(12) & 0.6548 & 1.96 & 99.2 & 3.42 & 3.20 & 18.3 \\
\hline 6 & $\mathbf{T i}^{2} \mathbf{L}_{3}$ & C6(12) & 1.2367 & 3.71 & 104.2 & 15.12 & 2.82 & 9.6 \\
\hline 7 & $\mathbf{T i}^{2} \mathbf{L}_{4}$ & C6(12) & 0.9662 & 2.90 & 88.9 & 14.51 & 2.75 & 7.7 \\
\hline 8 & $\mathbf{T i}^{2} \mathbf{L}_{5}$ & C6(12) & 1.0759 & 3.23 & 93.3 & 12.93 & 2.39 & 6.3 \\
\hline $9^{f}$ & $\mathrm{TiL}_{6}$ & C6(12) & 1.8898 & 5.67 & 106.7 & 3.36 & 3.04 & 17.2 \\
\hline 10 & $\mathbf{T i}^{2} \mathbf{L}_{2}$ & $\mathrm{C} 8(12)$ & 1.5343 & 4.60 & 97.1 & & & 5.5 \\
\hline 11 & $\mathbf{T i}^{2} \mathbf{L}_{2}$ & $\mathrm{C} 10(12)$ & 1.7985 & 5.40 & 96.9 & & & 8.4 \\
\hline
\end{tabular}

${ }^{a}$ Toluene $30 \mathrm{ml}, 2 \mu \mathrm{mol}$ of catalyst, 1 atm ethylene pressure, $1000 \mathrm{Al} / \mathrm{Ti}$ molar ratio, polymerization temperature $30{ }^{\circ} \mathrm{C}$, reaction time 5 min. ${ }^{b}$ Activity, $10^{6} \mathrm{~g}$ mol $(\mathrm{Ti})^{-1} \mathrm{~h}^{-1} \mathrm{~atm}^{-1}$. ${ }^{c}$ Melting temperature determined by DSC. ${ }^{d} 10^{4} \mathrm{~g} \mathrm{~mol}^{-1}$, determined by GPC using polystyrene standard.

${ }^{e}$ Determined by high temperature ${ }^{13} \mathrm{C}$ NMR. ${ }^{f} 4 \mu \mathrm{mol}$ of catalyst. 


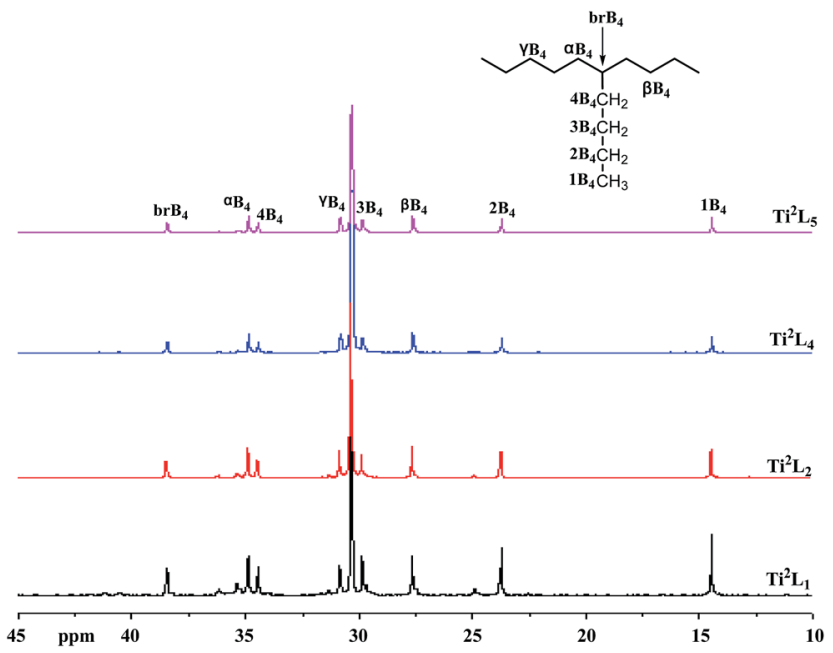

Fig. $5{ }^{13} \mathrm{C}$ NMR spectra of PE samples from entries 2, 5, 7 and 8 in Table 4.

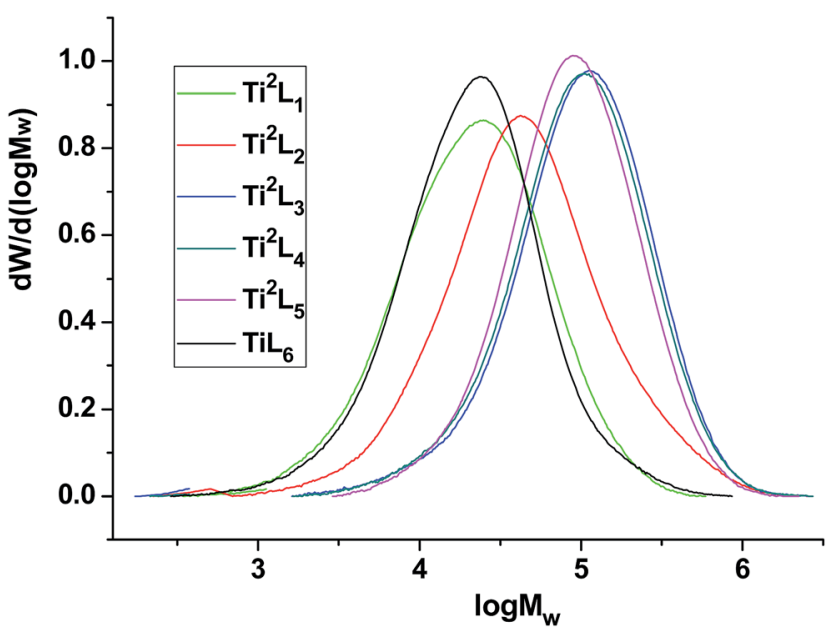

Fig. 6 GPC curves of the ethylene/1-hexene copolymers obtained with bi- and mono-nuclear Ti complexes.

(entry 10 and 11, Table 4) compared with ethylene/1-hexene copolymerization.

\section{Conclusions}

A series of phenyl-bridged bis- $\beta$-carbonylenamine $\left[\mathrm{ONS}^{\mathrm{R}}\right](\mathrm{R}=$ alkyl or phenyl) tridentate ligands $\mathbf{L}_{\mathbf{1}}-\mathbf{L}_{\mathbf{5}}$ and their binuclear titanium complexes $\mathbf{T i}^{2} \mathbf{L}_{\mathbf{1}}-\mathbf{T i}^{\mathbf{2}} \mathbf{L}_{\mathbf{5}}$ were synthesized and characterized. The molecular structures of ligand $\mathbf{L}_{2}\left(\mathrm{R}={ }^{n} \mathrm{Pr}\right)$ and its corresponding Ti complex $\mathbf{T i}^{2} \mathbf{L}_{2}$ as studied by single-crystal $\mathrm{X}$-ray diffraction revealed that each titanium coordinated with an oxygen, a nitrogen, a sulfur and three chlorine atoms to form a distorted octahedral configuration. Furthermore, the alkylthio or phenylthio anilines reacted with the carbonyl groups adjacent to phenylene group, resulting in isolated and relatively independent titanium centers in the complex. Compared with the mononuclear analogue $\mathbf{T i L}_{\mathbf{6}}$, these complexes exhibited better thermal stability for ethylene polymerization and produced PE with higher molecular weight and wider polydispersity, suggesting that two active centers were formed. The molecular weight and $\alpha$-olefin incorporation ratio can be flexibly tuned by the catalyst structure. The complex $\mathbf{T i}^{\mathbf{2}} \mathbf{L}_{5}$ which bears phenylthio sidearm exhibited higher activity towards ethylene polymerization and produced polyethylene with much higher molecular weight compared with the complexes bearing alkylthio sidearms, but resulted in lower 1-hexene incorporation ratio. Meanwhile, the 1-hexene incorporation ratio could also be tuned by the initial feed of the $\alpha$-olefin commoner. However, this type of binuclear titanium complexes showed weak or negligible bimetallic cooperative effects due to the far separation of the titanium centers.

\section{Experimental section}

\subsection{General procedures}

All manipulations involving air- and/or moisture-sensitive compounds were performed under dry nitrogen using standard Schlenk-line and glovebox. Toluene and hexane were purified by distillation over sodium/benzophenone ketyl, while $\mathrm{CH}_{2} \mathrm{Cl}_{2}$ was refluxed over $\mathrm{CaH}_{2}$. Gases and other solvents were purified by standard techniques. Modified methylaluminoxane (MMAO) was purchased from Akzo Chemical as a $7 \mathrm{wt} \%$ solution in heptane. All other chemical reagents were used as received unless noted otherwise.

${ }^{1} \mathrm{H}$ and ${ }^{13} \mathrm{C}$ NMR spectra of ligands and complexes were recorded on a Bruker Avance III $400 \mathrm{MHz}$ spectrometer with tetramethylsilane as an internal standard. Elemental analyses were carried out using Vario EL 111. ${ }^{13} \mathrm{C}$ NMR spectra of polymers were obtained on a Varian XL $300 \mathrm{MHz}$ spectrometer at $120{ }^{\circ} \mathrm{C}$ with $o-\mathrm{C}_{6} \mathrm{D}_{4} \mathrm{Cl}_{2}$ as the solvent. IR spectra were collected with a Nicolet Nexus 470 Fourier transform infrared (FTIR) spectrometer. DSC measurements were performed on a Netzsch DSC200 F3 instrument at a heating rate of $10{ }^{\circ} \mathrm{C} \mathrm{min}^{-1}$ from 20 to $160{ }^{\circ} \mathrm{C}$, with the melting points obtained from the endothermic peak of the second heating scan. The $M_{\mathrm{n}}$ and $M_{\mathrm{w}} / M_{\mathrm{n}}$ of the polymers were determined at $150{ }^{\circ} \mathrm{C}$ with a Viscotek $350 \mathrm{~A}$ HT-GPC System using a polystyrene calibration. 1,2,4-Trichlorobenzene was employed as the solvent at a flow rate of $1.0 \mathrm{~mL} \mathrm{~min}^{-1}$.

\subsection{Synthesis of the ligands and binuclear titanium complexes}

4.2.1 1,1'-(1,3-Phenylene)-bis-(4,4-dimethylpentane-1,3-dione) (2). $2.9 \mathrm{~g}$ of dimethyl isophthalate (1), $3.7 \mathrm{~g}$ of pinacolone, $4.6 \mathrm{~g}$ of sodium amide and $40 \mathrm{ml}$ of absolute ether dried by sodium were added to a $100 \mathrm{ml}$ 3-neck flask, and stirred at $0{ }^{\circ} \mathrm{C}$ for $2 \mathrm{~h}$, and then warmed to RT to react for another $2 \mathrm{~h}$. The reaction was quenched by $50 \mathrm{ml}$ ice water, then an orange yellow solid was produced, which was washed with ice ethanol for three times to obtain $3.2 \mathrm{~g}$ of off-white product with $65 \%$ yield. ${ }^{1} \mathrm{H} \mathrm{NMR}\left(400 \mathrm{MHz}, \mathrm{CDCl}_{3}\right)$ : $\delta 8.40(\mathrm{~s}, 1 \mathrm{H}), 8.04(\mathrm{~s}, 2 \mathrm{H}), 7.56(\mathrm{~d}, J=7.8 \mathrm{~Hz}, 1 \mathrm{H}), 6.36(\mathrm{~s}, 2 \mathrm{H})$, $1.28(\mathrm{~s}, 18 \mathrm{H})$. Anal. calcd for $\mathrm{C}_{20} \mathrm{H}_{26} \mathrm{O}_{4}: \mathrm{C}, 72.70 ; \mathrm{H}, 7.93 \%$. Found: C, 72.32; H, 7.96\%. 
4.2.2 4,4-Dimethyl-1-phenylpentane-1,3-dione (4). 4 was synthesized with a similar procedure as for $2 .{ }^{1} \mathrm{H}$ NMR $\left(400 \mathrm{MHz}, \mathrm{CDCl}_{3}\right): \delta 7.92(\mathrm{~s}, 2 \mathrm{H}), 7.52(\mathrm{~s}, 1 \mathrm{H}), 7.46(\mathrm{~d}, J=6.2 \mathrm{~Hz}$, $2 \mathrm{H}), 6.33(\mathrm{~s}, 1 \mathrm{H}), 1.28(\mathrm{~s}, 9 \mathrm{H})$. Anal. calcd for $\mathrm{C}_{13} \mathrm{H}_{16} \mathrm{O}_{2}: \mathrm{C}, \mathrm{C}$, 76.44; H, 7.90\%. Found: C, 76.85; H, 7.46\%.

\subsubsection{Ligands $\mathrm{L}_{\mathbf{1}}-\mathrm{L}_{6}$}

$\boldsymbol{L}_{1}$. To a $100 \mathrm{ml}$ 3-neck flask were added $0.6837 \mathrm{~g}$ of $2,0.6791 \mathrm{~g}$ of methylthio aniline, $40 \mathrm{ml}$ of toluene, and $0.1 \mathrm{~g}$ of $p$-toluene sulfonic acid ( $\mathrm{TsOH}$ ) as catalyst, and heated to reflux for $24 \mathrm{~h}$. The mixture was then vacuum dried, and recrystallized with ethanol to afford $\mathbf{L}_{\mathbf{1}}$ as a yellow solid with $78 \%$ yield. ${ }^{1} \mathrm{H}$ NMR $(400 \mathrm{MHz}$, $\left.\mathrm{CDCl}_{3}\right): \delta 12.05(\mathrm{~s}, 1 \mathrm{H}), 7.30(\mathrm{~s}, 1 \mathrm{H}), 7.25(\mathrm{~s}, 1 \mathrm{H}), 7.23(\mathrm{~d}, J=$ $5.0 \mathrm{~Hz}, 1 \mathrm{H}), 7.21-7.13(\mathrm{~m}, 1 \mathrm{H}), 7.00(\mathrm{t}, J=7.7 \mathrm{~Hz}, 1 \mathrm{H}), 6.79(\mathrm{t}, J=$ $7.6 \mathrm{~Hz}, 1 \mathrm{H}), 6.19(\mathrm{~d}, J=7.7 \mathrm{~Hz}, 1 \mathrm{H}), 5.45(\mathrm{~s}, 1 \mathrm{H}), 2.51(\mathrm{~s}, 3 \mathrm{H}), 1.24$ $(\mathrm{d}, J=21.4 \mathrm{~Hz}, 9 \mathrm{H}) .{ }^{13} \mathrm{C} \mathrm{NMR}\left(101 \mathrm{MHz}, \mathrm{CDCl}_{3}\right): \delta 206.30(C=\mathrm{O})$, 158.87 (Ar-NH-C), 137.91, 136.55, 132.38, 129.14, 128.52, 127.94, 126.51, 125.14, 124.75, 124.71 (Ar-C), 97.14, 42.56, 27.60, 15.53. Anal. calcd for $\mathrm{C}_{34} \mathrm{H}_{40} \mathrm{~N}_{2} \mathrm{O}_{2} \mathrm{~S}_{2}$ : C, 71.29; H, 7.04; N, 4.89\%. Found: C, 71.38; H, 6.92; N, 4.75\%. IR (KBr, $\left.\mathrm{cm}^{-1}\right)$ : 3452, 3070, 2964, 1608, 1501, 1475, 1441, 1325, 1219, 1122, 1087, 751.

Ligands $\mathbf{L}_{2}-\mathbf{L}_{\mathbf{6}}$ were synthesized with a similar procedure as for $\mathbf{L}_{\mathbf{1}}$.

$\boldsymbol{L}_{2}$. Yield: $80 \% .{ }^{1} \mathrm{H}$ NMR (400 $\left.\mathrm{MHz}, \mathrm{CDCl}_{3}\right): \delta 12.06(\mathrm{~s}, 2 \mathrm{H})$, $7.31(\mathrm{~s}, 1 \mathrm{H}), 7.30(\mathrm{~s}, 2 \mathrm{H}), 7.24(\mathrm{~d}, J=7.1 \mathrm{~Hz}, 2 \mathrm{H}), 7.19(\mathrm{~d}, J=$ $8.6 \mathrm{~Hz}, 1 \mathrm{H}), 6.95(\mathrm{t}, J=7.3 \mathrm{~Hz}, 2 \mathrm{H}), 6.81(\mathrm{t}, J=7.3 \mathrm{~Hz}, 2 \mathrm{H}), 6.20$ $(\mathrm{d}, J=7.9 \mathrm{~Hz}, 2 \mathrm{H}), 2.93(\mathrm{t}, J=7.3 \mathrm{~Hz}, 4 \mathrm{H}), 1.81-1.67(\mathrm{~m}, 4 \mathrm{H})$, $1.21(\mathrm{~s}, 18 \mathrm{H}), 1.07$ (t, $J=7.4 \mathrm{~Hz}, 6 \mathrm{H}) .{ }^{13} \mathrm{C}$ NMR $(101 \mathrm{MHz}$, $\left.\mathrm{CDCl}_{3}\right): \delta 206.13(C=\mathrm{O}), 158.43(\mathrm{Ar}-\mathrm{NH}-C), 139.19,136.73$, 130.21, 129.50, 129.11, 126.74, 125.82, 125.54, 124.97, 124.31 $(\mathrm{Ar}-\mathrm{C}), 97.35,42.56,34.97,27.61,22.50,13.62$. Anal. calcd for $\mathrm{C}_{38} \mathrm{H}_{48} \mathrm{~N}_{2} \mathrm{O}_{2} \mathrm{~S}_{2}$ : C, 72.57; H, 7.69; N, 4.45\%. Found: C, 72.83; H, 7.88; N, 4.16\%. IR (KBr, cm ${ }^{-1}$ ): 3446, 3063, 2959, 2868, 1615, 1589, 1571, 1533, 1497, 1474, 1451, 1325, 1286, 1123, 1088, 751.

$\boldsymbol{L}_{3}$. Yield: $68 \%$. ${ }^{1} \mathrm{H}$ NMR (400 $\left.\mathrm{MHz}, \mathrm{CDCl}_{3}\right): \delta 12.14(\mathrm{~s}, 1 \mathrm{H})$, 7.39 (d, $J=6.6 \mathrm{~Hz}, 1 \mathrm{H}), 7.29(\mathrm{~s}, 1 \mathrm{H}), 7.25(\mathrm{~s}, 1 \mathrm{H}), 6.90(\mathrm{~d}, J=$ $21.1 \mathrm{~Hz}, 2 \mathrm{H}), 6.22(\mathrm{~s}, 1 \mathrm{H}), 5.45(\mathrm{~s}, 1 \mathrm{H}), 3.48(\mathrm{~s}, 1 \mathrm{H}), 1.38(\mathrm{~s}, 5 \mathrm{H})$, $1.21(\mathrm{~s}, 9 \mathrm{H}) .{ }^{13} \mathrm{C}$ NMR $\left(101 \mathrm{MHz}, \mathrm{CDCl}_{3}\right): \delta 203.30(C=\mathrm{O}), 183.66$ (Ar-NH-C), 150.68, 138.85, 137.37, 136.14, 131.15, 130.33, 128.94, 125.87, 125.48, 117.36 (Ar-C), 92.40, 39.97, 36.12, 27.40, 23.02. Anal. calcd for $\mathrm{C}_{38} \mathrm{H}_{48} \mathrm{~N}_{2} \mathrm{O}_{2} \mathrm{~S}_{2}$ : C, 72.57; H, 7.69; N, 4.45\%. Found: C, 72.29; H, 7.35; N, 4.68\%. IR (KBr, $\left.\mathrm{cm}^{-1}\right): 3451,3061$, 2966, 1623, 1386, 1316, 1189, 1088, 569, 461.

$\boldsymbol{L}_{\boldsymbol{4}}$. Yield: $78 \% .{ }^{1} \mathrm{H}$ NMR (400 MHz, $\left.\mathrm{CDCl}_{3}\right): \delta 12.08(\mathrm{~d}, J=$ $20.4 \mathrm{~Hz}, 2 \mathrm{H}), 7.30$ (d, $J=4.1 \mathrm{~Hz}, 2 \mathrm{H}), 7.29$ (s, 1H), 7.27-7.22 (m, $2 \mathrm{H}), 7.22-7.14(\mathrm{~m}, 1 \mathrm{H}), 6.95(\mathrm{t}, J=7.7 \mathrm{~Hz}, 2 \mathrm{H}), 6.80(\mathrm{t}, J=7.5 \mathrm{~Hz}$, $2 \mathrm{H}), 6.20(\mathrm{~d}, J=8.2 \mathrm{~Hz}, 2 \mathrm{H}), 5.44(\mathrm{~s}, 2 \mathrm{H}), 2.94(\mathrm{t}, J=7.4 \mathrm{~Hz}, 4 \mathrm{H})$, 1.77-1.67 (m, 4H), 1.46 (dd, $J=13.4,6.5 \mathrm{~Hz}, 4 \mathrm{H}), 1.29$ (dd, $J=$ 9.8, 4.0 Hz, 16H), 1.21 (s, 18H), 0.89 (t, $J=6.5 \mathrm{~Hz}, 6 \mathrm{H}) .{ }^{13} \mathrm{C}$ NMR $\left(101 \mathrm{MHz}, \mathrm{CDCl}_{3}\right): \delta 206.02(C=\mathrm{O}), 158.39$ (Ar-NH-C), 139.26, 136.78, 130.38, 129.56, 129.09, 128.47, 127.93, 125.53, 124.93, 124.28 (Ar-C), 97.37, 42.54, 39.24, 33.16, 31.82, 29.19, 28.97, 28.70, 27.61, 22.65, 14.10. Anal. calcd for $\mathrm{C}_{48} \mathrm{H}_{68} \mathrm{~N}_{2} \mathrm{O}_{2} \mathrm{~S}_{2}: \mathrm{C}$, 74.95; H, 8.91; N, 3.64\%. Found: C, 74.59; H, 8.62; N, 3.91\%. IR $\left(\mathrm{KBr}, \mathrm{cm}^{-1}\right): 3448,3061,2926,2858,1608,1564,1466,1315$, 1220, 1188, 1100, 788 .
$\boldsymbol{L}_{5}$. Yield: $83 \% .{ }^{1} \mathrm{H}$ NMR $\left(400 \mathrm{MHz}, \mathrm{CDCl}_{3}\right): \delta 12.29(\mathrm{~s}, 2 \mathrm{H})$, $7.43-6.83(\mathrm{~m}, 22 \mathrm{H}), 6.20$ (d, $J=7.7 \mathrm{~Hz}, 2 \mathrm{H}), 1.21(\mathrm{~s}, 18 \mathrm{H}) .{ }^{13} \mathrm{C}$ NMR (101 MHz, $\mathrm{CDCl}_{3}$ ): $\delta 206.11(C=\mathrm{O}), 158.26(\mathrm{Ar}-\mathrm{NH}-C)$, 139.83, 136.59, 134.33, 132.50, 132.19, 129.48, 129.19, 128.94, 128.44, 127.73, 127.54, 127.16, 125.01, 124.37 (Ar-C), 97.24, 42.53, 27.61. Anal. calcd for $\mathrm{C}_{44} \mathrm{H}_{44} \mathrm{~N}_{2} \mathrm{O}_{2} \mathrm{~S}_{2}$ : C, 75.83; H, 6.36; N, 4.02\%. Found: C, 75.62; H, 6.53; N, 4.34\%. IR (KBr, $\left.\mathrm{cm}^{-1}\right): 3447$, 3059, 2964, 2865, 2360, 2342, 1616, 1571, 1558, 1497, 1475, 1439, 1289, 1120, 1089, 1023, 792, 750.

L6. Yield: $81 \% .{ }^{1} \mathrm{H}$ NMR (400 MHz, $\left.\mathrm{CDCl}_{3}\right): \delta 12.22(\mathrm{~s}, 1 \mathrm{H})$, $7.30(\mathrm{~d}, J=11.2 \mathrm{~Hz}, 6 \mathrm{H}), 6.85(\mathrm{~d}, J=47.5 \mathrm{~Hz}, 2 \mathrm{H}), 6.34(\mathrm{~s}, 1 \mathrm{H})$, $5.66(\mathrm{~s}, 1 \mathrm{H}), 2.95(\mathrm{~d}, J=4.7 \mathrm{~Hz}, 2 \mathrm{H}), 1.75(\mathrm{~s}, 2 \mathrm{H}), 1.26(\mathrm{~s}, 9 \mathrm{H})$, 1.09 (d, $J=8.5 \mathrm{~Hz}, 3 \mathrm{H}) .{ }^{13} \mathrm{C} \mathrm{NMR}\left(101 \mathrm{MHz}, \mathrm{CDCl}_{3}\right): \delta 205.91$ $(C=\mathrm{O}), 159.32$ (Ar-NH-C), 139.77, 136.51, 132.89, 130.15, 129.56, 129.41, 128.44, 128.35, 128.14, 125.88, 124.48, 123.90 $(\mathrm{Ar}-\mathrm{C}), 97.37,52.07,35.31,27.71,22.58,13.56$. Anal. calcd for $\mathrm{C}_{22} \mathrm{H}_{27} \mathrm{NOS}$ : C, 74.75; H, 7.70; N, 3.96\%. Found: C, 74.39; H, 7.57; N, 3.73\%. IR (KBr, $\mathrm{cm}^{-1}$ ): 3449, 2963, 1617, 1562, 1507, 1387, 1299, 1218, 1186, 1086, 802, 766.

\subsection{Binuclear titanium complexes $\left(\mathrm{Ti}^{2} \mathrm{~L}_{\mathbf{1}}-\mathrm{Ti}^{2} \mathbf{L}_{4}\right)$}

4.3.1 $\mathbf{T i}^{2} \mathbf{L}_{\mathbf{1}} \cdot 0.573 \mathrm{~g}(1 \mathrm{mmol})$ of ligand $\mathbf{L}_{\mathbf{1}}$ was added to a $100 \mathrm{ml}$ Schlenk flask, dissolved in $15 \mathrm{ml}$ of $\mathrm{CH}_{2} \mathrm{Cl}_{2}$. A solution of $\mathrm{TiCl}_{4}(0.28 \mathrm{ml}, 2.6 \mathrm{mmol})$ in $\mathrm{CH}_{2} \mathrm{Cl}_{2}(15 \mathrm{ml})$ was added to another $100 \mathrm{ml}$ Schlenk flask. The ligand solution was then slowly added to the $\mathrm{TiCl}_{4}$ solution at $-78{ }^{\circ} \mathrm{C}$. After 5 hours, the mixture was slowly warmed to RT, then heated to $35^{\circ} \mathrm{C}$ for $24 \mathrm{~h}$ under stirring. The solvent was vacuum dried to afford $\mathbf{T i}^{2} \mathbf{L}_{\mathbf{1}}$ as a red brown solid. Pure product was obtained by diffusing $n$ hexane into dichloromethane solution of $\mathbf{T i}^{2} \mathbf{L}_{\mathbf{1}}$ with $67 \%$ yield. ${ }^{1} \mathrm{H} \mathrm{NMR}\left(400 \mathrm{MHz}, \mathrm{CDCl}_{3}\right): \delta 7.50(\mathrm{~s}, 1 \mathrm{H}), 7.34(\mathrm{~s}, 1 \mathrm{H}), 7.14(\mathrm{t}, J=$ $7.3 \mathrm{~Hz}, 1 \mathrm{H}), 6.95(\mathrm{~s}, 2 \mathrm{H}), 6.21(\mathrm{~s}, 1 \mathrm{H}), 5.94(\mathrm{~s}, 1 \mathrm{H}), 3.15$ (d, $J=$ $28.7 \mathrm{~Hz}, 3 \mathrm{H}), 1.31$ (s, 9H). ${ }^{13} \mathrm{C} \mathrm{NMR}\left(101 \mathrm{MHz}, \mathrm{CDCl}_{3}\right): \delta 210.41$ $(=C-\mathrm{O}), 172.20(\mathrm{Ar}-\mathrm{N}=C), 166.35,151.34,130.31,130.02$, 128.90, 128.08, 128.04, 125.46, 117.14, 111.60 (Ar-C), 92.59, 39.53, 27.79, 14.11. Anal. calcd for $\mathrm{C}_{34} \mathrm{H}_{38} \mathrm{Cl}_{6} \mathrm{~N}_{2} \mathrm{O}_{2} \mathrm{~S}_{2} \mathrm{Ti}_{2}$ : C, 46.45; H, 4.36; N, 3.19\%. Found: C, 46.82; H, 4.73; N, 3.31\%. IR $\left(\mathrm{KBr}, \mathrm{cm}^{-1}\right): 3070,2962,2931,2875,1706,1609,1558,1458$, 1318, 1275, 1211, 1125, 1091, 765.

Complexes $\mathbf{T i}^{2} \mathbf{L}_{2}-\mathbf{T i}^{2} \mathbf{L}_{5}$ were prepared using the same procedure as for $\mathbf{T i}^{\mathbf{2}} \mathbf{L}_{\mathbf{1}}$.

4.3.2 $\mathbf{T i}^{2} \mathbf{L}_{2}$. Yield: $75 \% .{ }^{1} \mathrm{H}$ NMR (400 MHz, $\left.\mathrm{CDCl}_{3}\right): \delta 7.57$ (d, $J=7.0 \mathrm{~Hz}, 1 \mathrm{H}), 7.33$ (d, $J=6.7 \mathrm{~Hz}, 1 \mathrm{H}), 7.19$ (dd, $J=7.7$, $3.1 \mathrm{~Hz}, 1 \mathrm{H}), 7.13(\mathrm{t}, J=7.6 \mathrm{~Hz}, 1 \mathrm{H}), 6.99(\mathrm{~s}, 1 \mathrm{H}), 6.24(\mathrm{~d}, J=$ $20.7 \mathrm{~Hz}, 1 \mathrm{H}), 6.01(\mathrm{~s}, 1 \mathrm{H}), 3.52(\mathrm{~s}, 2 \mathrm{H}), 2.10(\mathrm{dd}, J=14.8,7.3 \mathrm{~Hz}$, 2H), $1.32(\mathrm{~s}, 9 \mathrm{H}), 1.23(\mathrm{t}, J=7.3 \mathrm{~Hz}, 3 \mathrm{H}) .{ }^{13} \mathrm{C} \mathrm{NMR}(101 \mathrm{MHz}$, $\left.\mathrm{CDCl}_{3}\right): \delta 204.32(=C-\mathrm{O}), 165.78(\mathrm{Ar}-\mathrm{N}=C), 149.71,141.36$, $139.37,136.75,129.63,126.57,125.01,117.34,115.96,113.45$, 113.20, 111.53 (Ar-C), 98.55, 31.58, 27.55, 22.64, 14.10, 13.56. Anal. calcd for $\mathrm{C}_{38} \mathrm{H}_{46} \mathrm{Cl}_{6} \mathrm{~N}_{2} \mathrm{O}_{2} \mathrm{~S}_{2} \mathrm{Ti}_{2}$ : C, 48.80; H, 4.96; N, 3.00\%. Found: C, 49.25; H, 4.64; N, 3.43\%. IR (KBr, $\left.\mathrm{cm}^{-1}\right): 2965,1620$, 1563, 1460, 1289, 1208, 1091, 838, 756.

4.3.3 $\mathbf{T i}^{2} \mathbf{L}_{3}$. Yield: $80 \%$. ${ }^{1} \mathrm{H}$ NMR $\left(400 \mathrm{MHz}, \mathrm{CDCl}_{3}\right) \delta 7.56$ $(\mathrm{d}, J=7.9 \mathrm{~Hz}, 2 \mathrm{H}), 7.15$ (dd, $J=35.8,18.6 \mathrm{~Hz}, 3 \mathrm{H}), 6.40(\mathrm{~s}, 1 \mathrm{H})$, $6.09(\mathrm{~s}, 1 \mathrm{H}), 4.14(\mathrm{~s}, 1 \mathrm{H}), 1.63(\mathrm{~s}, 6 \mathrm{H}), 1.32(\mathrm{~s}, 9 \mathrm{H}) .{ }^{13} \mathrm{C}$ NMR $\left(101 \mathrm{MHz}, \mathrm{CDCl}_{3}\right): \delta 199.20(=C-\mathrm{O}), 181.31(\mathrm{Ar}-\mathrm{N}=C), 160.32$, 
139.43, 136.34, 131.05, 129.67, 129.26, 128.02, 124.41, 112.45, $103.22(\mathrm{Ar}-\mathrm{C}), 93.69,31.58,27.82,27.54,23.08$. Anal. calcd for $\mathrm{C}_{38} \mathrm{H}_{46} \mathrm{Cl}_{6} \mathrm{~N}_{2} \mathrm{O}_{2} \mathrm{~S}_{2} \mathrm{Ti}_{2}$ : C, 48.80; $\mathrm{H}, 4.96 ; \mathrm{N}, 3.00 \%$. Found: C, 48.51; H, 5.30; N, 2.76\%. IR (KBr, $\left.\mathrm{cm}^{-1}\right): 2964,1617,1558,1497$, 1475, 1290, 1120, 1088, 884, 791, 755.

4.3.4 $\mathbf{T i}^{2} \mathbf{L}_{4}$. Yield: $74 \%$. ${ }^{1} \mathrm{H}$ NMR (400 MHz, $\left.\mathrm{CDCl}_{3}\right): \delta 7.57$ $(\mathrm{d}, J=7.7 \mathrm{~Hz}, 2 \mathrm{H}), 7.13(\mathrm{t}, J=6.9 \mathrm{~Hz}, 1 \mathrm{H}), 6.99(\mathrm{~s}, 2 \mathrm{H}), 6.27(\mathrm{~s}$, $1 \mathrm{H}), 6.01(\mathrm{~s}, 1 \mathrm{H}), 3.54(\mathrm{~s}, 2 \mathrm{H}), 2.10-2.01(\mathrm{~m}, 2 \mathrm{H}), 1.63-1.57(\mathrm{~m}$, $2 \mathrm{H}), 1.43(\mathrm{~d}, J=9.2 \mathrm{~Hz}, 3 \mathrm{H}), 1.37(\mathrm{~d}, J=8.0 \mathrm{~Hz}, 9 \mathrm{H}), 1.28(\mathrm{~s}, 8 \mathrm{H})$. ${ }^{13} \mathrm{C} \mathrm{NMR}\left(101 \mathrm{MHz}, \mathrm{CDCl}_{3}\right): \delta 206.10(=C-\mathrm{O}), 157.75(\mathrm{Ar}-\mathrm{N}=C)$, 139.10, 136.71, 130.39, 129.34, 129.12, 127.91, 125.47, 124.96, 124.32, 111.80 (Ar- $C$ ), 97.36, 42.57, 33.04, 31.83, 31.61, 29.21, 29.14, 27.83, 27.61, 22.67, 14.16. Anal. calcd for $\mathrm{C}_{48} \mathrm{H}_{66} \mathrm{Cl}_{6} \mathrm{~N}_{2}$ $\mathrm{O}_{2} \mathrm{~S}_{2} \mathrm{Ti}_{2}: \mathrm{C}, 53.60 ; \mathrm{H}, 6.19 ; \mathrm{N}, 2.60 \%$. Found: C, 53.39; H, 6.37; N, $2.81 \%$. IR ( $\left.\mathrm{KBr}, \mathrm{cm}^{-1}\right): 2956,2925,2854,1617,1574,1560,1483$, 1461, 1264, 1146, 891, 762.

4.3.5 $\mathbf{T i}^{2} \mathbf{L}_{5}$. Yield: $68 \% .{ }^{1} \mathrm{H}$ NMR $\left(400 \mathrm{MHz}, \mathrm{CDCl}_{3}\right): \delta 7.50-$ $7.28(\mathrm{~m}, 22 \mathrm{H}), 5.83(\mathrm{~s}, 2 \mathrm{H}), 0.90(\mathrm{t}, J=6.5 \mathrm{~Hz}, 18 \mathrm{H}) .{ }^{13} \mathrm{C} \mathrm{NMR}$ $\left(101 \mathrm{MHz} \mathrm{CDCl}_{3}\right) \delta 203.48(=C-\mathrm{O}), 173.45(\mathrm{Ar}-\mathrm{N}=C), 156.12$, 147.72, 144.86, 139.70, 134.83, 134.21, 132.26, 130.47, 129.63, 129.50, 129.43, 121.37, 109.07, 107.56 (Ar-C), 86.99, 31.58, 22.65. Anal. calcd for $\mathrm{C}_{44} \mathrm{H}_{42} \mathrm{Cl}_{6} \mathrm{~N}_{2} \mathrm{O}_{2} \mathrm{~S}_{2} \mathrm{Ti}_{2}$ : C, 52.67; H, 4.22; N, 2.79\%. Found: C, 52.18; H, 4.86; N, 3.31\%. IR (KBr, $\left.\mathrm{cm}^{-1}\right): 3331,2963$, $1707,1557,1496,1475$, 1439, 1347, 1290, 1210, 1122, 1087, 1059, 1023, 793, 750, 691.

\subsection{Mononuclear titanium complex $\left(\mathrm{TiL}_{6}\right)$}

$\mathbf{T i L}_{\mathbf{6}}$ was prepared using the same procedure as for $\mathbf{T i}^{2} \mathbf{L}_{\mathbf{1}}$, except that the molar ratio of ligand $\mathbf{L}_{6}$ and $\mathrm{TiCl}_{4}$ was $1: 1.2$. Yield: $80 \% .{ }^{1} \mathrm{H}$ NMR $\left(400 \mathrm{MHz}, \mathrm{CDCl}_{3}\right) \delta 7.53(\mathrm{~d}, J=7.7 \mathrm{~Hz}, 1 \mathrm{H}), 7.39$ $(\mathrm{d}, J=7.4 \mathrm{~Hz}, 1 \mathrm{H}), 7.34(\mathrm{t}, J=7.3 \mathrm{~Hz}, 2 \mathrm{H}), 7.21(\mathrm{~d}, J=6.0 \mathrm{~Hz}$, $2 \mathrm{H}), 7.06(\mathrm{t}, J=7.1 \mathrm{~Hz}, 1 \mathrm{H}), 6.92(\mathrm{t}, J=7.6 \mathrm{~Hz}, 1 \mathrm{H}), 6.45(\mathrm{~d}, J=$ $8.2 \mathrm{~Hz}, 1 \mathrm{H}), 6.26(\mathrm{~s}, 1 \mathrm{H}), 3.50(\mathrm{~s}, 2 \mathrm{H}), 2.06(\mathrm{dd}, J=14.9,7.5 \mathrm{~Hz}$, $2 \mathrm{H}), 1.36(\mathrm{~s}, 9 \mathrm{H}), 1.21(\mathrm{t}, J=7.4 \mathrm{~Hz}, 3 \mathrm{H}) .{ }^{13} \mathrm{C} \mathrm{NMR}(101 \mathrm{MHz}$, $\left.\mathrm{CDCl}_{3}\right): \delta 190.20(=C-\mathrm{O}), 173.64(\mathrm{Ar}-\mathrm{N}=C), 152.70,138.76$, 133.40, 133.36, 130.56, 129.59, 129.15, 128.67, 128.51, 127.33, 125.72, 112.00 (Ar-C), 100.13, 47.03, 39.50, 27.81, 21.81, 13.36. Anal. calcd for $\mathrm{C}_{22} \mathrm{H}_{26} \mathrm{Cl}_{3} \mathrm{NOSTi}$ : C, 52.15; H, 5.17; N, 2.76\%. Found: C, 52.58; H, 5.49; N, 2.36\%. IR (KBr, $\left.\mathrm{cm}^{-1}\right): 2964,1617$, 1559, 1506, 1087, 769.

\subsection{Crystallographic analysis}

Crystal data were collected on a Bruker APEX-II CCD diffractometer with graphite-monochromated Mo $\mathrm{K} \alpha$ radiation $(\lambda=$ $0.71073 \AA$ ) at $130 \mathrm{~K}$ for $\mathbf{T i}^{2} \mathbf{L}_{2}$. Crystals were coated in oil and then directly mounted on the diffractometer under a stream of cold nitrogen gas. A total of $\mathrm{N}$ reflections were collected by using $\omega$ scan mode. Corrections were applied for Lorentz and polarization effects as well as absorption using multi-scans (SADABS). All the structures were solved by direct method (SHELXS-97). The remaining non-hydrogen atoms were obtained from the successive difference Fourier maps. All non-H atoms were refined with anisotropic displacement parameters, while the $\mathrm{H}$ atoms were constrained to the parent sites, using a riding mode (SHELXTL). Details of the X-ray structure determinations and refinements are provided in Table 1. Other details are shown in the ESI. $\dagger$ CCDC numbers for $\mathbf{L}_{2}$ and $\mathbf{T i}^{2} \mathbf{L}_{2}$ are CCDC 1587147 and $1587146, \dagger$ respectively.

\subsection{Ethylene polymerization and copolymerization}

A flame-dried Schlenk flask purged with $\mathrm{N}_{2}$ was filled with ethylene gas. $30 \mathrm{ml}$ of freshly distilled toluene was added and raised to the reaction temperature for $10 \mathrm{~min}$. MMAO was then injected using a syringe and the mixture was stirred for $5 \mathrm{~min}$. The polymerization was initiated by adding a solution of the titanium complex in toluene with a syringe. After a desired time, the polymerization was quenched with acidified ethanol (100 mL, $8 \mathrm{vol} \% \mathrm{HCl}$ in ethanol). The precipitated polymer was filtered off, washed with ethanol, then dried under vacuum overnight at $60{ }^{\circ} \mathrm{C}$ till a constant weight. For copolymerization, $\alpha$-olefins (1-hexene, 1-octene or 1-decene) and MMAO were injected in sequence via a syringe.

\section{Conflicts of interest}

There are no conflicts to declare.

\section{Acknowledgements}

The authors are grateful for the financial support from the National Natural Science Foundation of China (21172269).

\section{Notes and references}

1 (a) H. Sinn and W. Kaminsky, Adv. Organomet. Chem., 1980, 18, 99; (b) H. Sinn, W. Kaminsky, H. J. Vollmer and R. Woldt, Angew. Chem., Int. Ed., 1980, 19, 390; (c) H. G. Alt and A. Köppl, Chem. Rev., 2000, 100, 1205; (d) L. Resconi, L. Cavallo, A. Fait and F. Piemontesi, Chem. Rev., 2000, 100, 1253; (e) G. Fink, B. Steinmetz, J. Zechlin, C. Przybyla and B. Tesche, Chem. Rev., 2000, 100, 1377; (f) G. W. Coates, Chem. Rev., 2000, 100, 1223.

2 Selected review article, see: $(a)$ G. J. P. Britovsek, V. C. Gibson and D. F. Wass, Angew. Chem., Int. Ed., 1999, 38, 428; (b) S. D. Ittel, L. K. Johnson and M. Brookhart, Chem. Rev., 2000, 100, 1169; (c) S. Mecking, Angew. Chem., Int. Ed., 2001, 40, 534; (d) V. C. Gibson and S. K. Spitzmesser, Chem. Rev., 2003, 103, 283; (e) L. Bourget-Merle, M. F. Lappert and J. R. Severn, Chem. Rev., 2002, 102, 3031; (f) V. C. Gibson, C. Redshaw and G. A. Solan, Chem. Rev., 2007, 107, 1745; $(g)$ K. Nomura and S. Zhang, Chem. Rev., 2011, 111, 2342; (h) S. Budagumpi, K. H. Kim and I. Kim, Coord. Chem. Rev., 2011, 255, 2785; (i) D. Zhang and G. Zi, Chem. Soc. Rev., 2015, 44, 1898; (j) B. L. Small, Acc. Chem. Res., 2015, 48, 2599; (k) H. Mu, L. Pan, D. Song and Y. Li, Chem. Rev., 2015, 115, 12091.

3 Selected recent references: (a) C. Rong, F. Wang, W. Li and M. Chen, Organometallics, 2017, 36, 4458; (b) Z. Chen, X. Zhao, X. Gong, D. Xu and Y. Ma, Macromolecules, 2017, 50, 6561; (c) P. Ji, J. B. Solomon, Z. Lin, A. Johnson, R. F. Jordan and W. Lin, J. Am. Chem. Soc., 2017, 139, 11325; (d) Z. Chen, E. Yao, J. Wang, X. Gong and Y. Ma, 
Macromolecules, 2016, 49, 8848; (e) M. Zhao and C. Chen, ACS Catal., 2017, 7, 7490; (f) D. Zhang, Y. Zhang, W. Hou, Z. Guan and Z. Huang, Organometallics, 2017, 36, 3758; $(g)$ P. Kenyon and S. Mecking, J. Am. Chem. Soc., 2017, 139, 13786; (h) K. Lian, Y. Zhu, W. Li, S. Dai and C. Chen, Macromolecules, 2017, 50, 6074; ( $i$ ) D. Bézier, O. Daugulis and M. Brookhart, Organometallics, 2017, 36, 2947; (j) S. Zhong, Y. Tan, L. Zhong, J. Gao, H. Liao, L. Jiang, H. Gao and Q. Wu, Macromolecules, 2017, 50, 5661; $(k)$ L. Zhong, G. Li, G. Liang, H. Gao and Q. Wu, Macromolecules, 2017, 50, 2675; (l) M. Chen and C. Chen, ACS Catal., 2017, 7, 1308; (m) F. Ölscher, I. Göttker-Schnetmann, V. Monteil and S. Mecking, J. Am. Chem. Soc., 2015, 137, 14819; (n) J. L. Rhinehart, L. A. Brown and B. K. Long, J. Am. Chem. Soc., 2013, 135, 16316; (o) D. Shoken, M. Sharma, M. Botoshansky, M. Tamm and M. S. Eisen, J. Am. Chem. Soc., 2013, 135, 12592; (p) D. Zhang and C. Chen, Angew. Chem., Int. Ed., 2017, 56, 14672; (q) M. Li, X. Wang, Y. Luo and C. Chen, Angew. Chem., Int. Ed., 2017, 56, 11604; (r) B. K. Long, J. M. Eagan, M. Mulzer and G. W. Coates, Angew. Chem., Int. Ed., 2016, 55, 7106; (s) L. Falivene, G. Boffa, S. O. Sánchez, L. Caporaso, A. Grassi and S. Mecking, Angew. Chem., Int. Ed., 2016, 55, 14378; $(t)$ Nakano, S. Ito and K. Nozaki, Angew. Chem., Int. Ed., 2016, 55, 2835; (u) Z. Jian and S. Mecking, Angew. Chem., Int. Ed., 2015, 54, 15845; (v) J. Sun, F. Wang, W. Lia and M. Chen, $R S C$ Adv., 2017, 7, 55051; (w) Y. Zhang, C. Huang, X. Hao, X. Hu and W.-H. Sun, $R S C A d v ., 2016,6$, 91401; $(x)$ X. Xiao, X. Hao, J. Bai, J. Chao, W. Cao and X. Chen, RSC Adv., 2016, 6, 60723; (y) W. Li, F. Su, S. Yuan, X. Duan, S. Bai and D. Liu, $R S C A d v ., 2016,6$, 40741; (z) S. Yuan, E. Yue, C. Wen and W.-H. Sun, RSC Adv., 2016, 6, 7431.

4 E. B. Tjaden, D. C. Swenson, R. F. Jordan and J. L. Petersen, Organometallics, 1995, 14, 371.

5 P. G. Cozzi, E. Gallo, C. Floriani, A. Chiesivilla and C. Rizzoli, Organometallics, 1995, 14, 4994.

6 (a) H. Makio and T. Fujita, Acc. Chem. Res., 2009, 42, 1532 and references therein; (b) T. Matsugi and T. Fujita, Chem. Soc. Rev., 2008, 37, 1264 and references therein; (c) H. Makio, H. Terao, A. Iwashita and T. Fujita, Chem. Rev., 2011, 111, 2363 and references therein; $(d)$ T. Fujita and K. Kawai, Top. Catal., 2014, 57, 852. and references therein.

7 (a) J. Tian and G. W. Coates, Angew. Chem., Int. Ed., 2000, 39, 3626; (b) J. Tian, P. D. Hustad and G. W. Coates, J. Am. Chem. Soc., 2001, 123, 5134; (c) P. D. Hustad and G. W. Coates, J. Am. Chem. Soc., 2002, 124, 11578; (d) A. F. Mason and G. W. Coates, J. Am. Chem. Soc., 2004, 126, 10798; (e) G. W. Coates, J. Am. Chem. Soc., 2008, 130, 4968.

8 (a) X.-F. Li, K. Dai, W.-P. Ye, L. Pan and Y.-S. Li, Organometallics, 2004, 23, 1223; (b) L. Pan, W.-P. Ye, J.-Y. Liu, M. Hong and Y.-S. Li, Macromolecules, 2008, 41, 2981; (c) L. Pan, M. Hong, J.-Y. Liu, W.-P. Ye and Y.-S. Li, Macromolecules, 2009, 42, 4391; (d) W.-P. Ye, J. Zhan, L. Pan, N.-H. Hu and Y.-S. Li, Organometallics, 2008, 27, 3642; (e) M. Hong, J.-Y. Liu, B.-X. Li and Y.-S. Li, Macromolecules, 2011, 44, 5659; $(f)$ M. Hong, Y.-X. Wang, H.-L. Mu and Y.-S. Li, Organometallics, 2011, 30, 4678.
9 (a) C. Redshaw and Y. Tang, Chem. Soc. Rev., 2012, 41, 4484 and references therein; (b) M. L. Gao, Y. F. Gu, C. Wang, X. L. Yao, X. L. Sun, C. F. Li, C. T. Qian, B. Liu, Z. Ma, Y. Tang, Z. W. Xie, S. Z. Bu and Y. Gao, J. Mol. Catal. A: Chem., 2008, 292, 62; (c) X.-H. Yang, Z. Wang, X.-L. Sun and Y. Tang, Dalton Trans., 2009, 8945; (d) Z. Chen, J.-F. Li, W.-J. Tao, X.-L. Sun, X.-H. Yang and Y. Tang, Macromolecules, 2013, 46, 2870; (e) C. Xu, Z. Chen, Q. Shen, X.-L. Sun and Y. Tang, J. Organomet. Chem., 2014, 761, 142.

10 (a) M. Delferro and T. J. Marks, Chem. Rev., 2011, 111, 2450 and references therein; (b) J. P. McInnis, M. Delferro and T. J. Marks, Acc. Chem. Res., 2014, 47, 2545 and references therein; (c) M. R. Salata and T. J. Marks, J. Am. Chem. Soc., 2008, 130, 12; (d) M. R. Salata and T. J. Marks, Macromolecules, 2009, 42, 1920.

11 (a) P. Buchwalter, J. Rosé and P. Braunstein, Chem. Rev., 2015, 115, 28; (b) I. Bratko and M. Gómez, Dalton Trans., 2013, 42, 10664.

12 (a) M. R. Radlauer, A. K. Buckley, L. M. Henling and T. Agapie, J. Am. Chem. Soc., 2013, 135, 3784; (b) M. R. Radlauer, M. W. Day and T. Agapie, J. Am. Chem. Soc., 2012, 134, 1478.

13 (a) S. L. Han, E. D. Yao, W. Qin, S. F. Zhang and Y. G. Ma, Macromolecules, 2012, 45, 4054; (b) Q. Yan, K. Tsutsumi and K. Nomura, RSC Adv., 2017, 7, 41345; (c) M. Khoshsefat, S. Ahmadjo, S. M. M. Mortazavia and G. H. Zohuri, RSC Adv., 2016, 6, 88625; (d) D. Mandal, D. Chakraborty, V. Ramkumar and D. K. Chand, RSC Adv., 2016, 6, 21706; (e) M. Zhou, Q. Yang, H. Tong, L. Yan and X. Wang, $R S C A d v$., 2015, 5, 105292; (f) C. Redshaw, M. J. Walton, M. R. J. Elsegood, T. J. Priorand and K. Michiue, $R S C$ Adv., 2015, 5, 89783; $(g)$ M. Mandal, D. Chakrabortyand and V. Ramkumar, RSC Adv., 2015, 5, 28536; (h) Q. Xing, T. Zhao, Y. Qiao, L. Wang, C. Redshawand and W.-H. Sun, RSC Adv., 2013, 3, 26184.

14 (a) G. Xie and C. Qian, J. Polym. Sci., Part A: Polym. Chem., 2008, 46, 211; (b) G. Xie, Y. Li, J. Sun and C. Qian, Inorg. Chem. Commun., 2009, 12, 796; (c) G. Xie, T. Li and A. Zhang, Inorg. Chem. Commun., 2010, 13, 1199; (d) G. Xie, G. Liu, L. Li, T. Li, A. Zhang and J. Feng, Catal. Commun., 2014, 45, 7; (e) G. Xie, X. Zhang, T. Li, L. Li, G. Liu and A. Zhang, J. Mol. Catal. A: Chem., 2014, 383-384, 121; (f) G. Xie, W. Song, T. Li, X. Xu, Z. Lan, Y. Li and A. Zhang, J. Appl. Polym. Sci., 2014, 131, 41178; (g) T. Li, W. Song, H. Ai, Q. You, A. Zhang and G. Xie, J. Polym. Res., 2015, 22, 631; (h) X. Xiao, Y. Wen, X. Wang, L. Lei, P. Xia, T. Li, A. Zhang and G. Xie, Russ. J. Coord. Chem., 2015, 41, 543; (i) L. Wang, X. You, Q. You, T. Li, A. Zhang and G. Xie, Transition Met. Chem., 2016, 41, 857.

15 (a) T. Li, Z. Lan, G. Xie, D. Luo, L. Li, S. Xiong, L. Zhang, L. Ouyang and A. Zhang, Catal. Lett., 2017, 147, 996; (b) L. Zhang, X. Chen, X. Xiao, D. Luo, Y. Zeng, T. Li, X. Li, A. Zhang and G. Xie, J. Organomet. Chem., 2018, 856, 50.

16 J. K. Clegg, D. J. Bray, K. Gloe, K. Gloe, K. A. Jolliffe, G. A. Lawrance, L. F. Lindoy, G. V. Meehane and M. Wenzel, Dalton Trans., 2008, 1331. 